\title{
Going Fiscal? A Stylised Model with Fiscal Capacity and a Safe Asset in the Eurozone
}

\author{
Lorenzo Codogno ${ }^{1}$ and Paul van den Noord ${ }^{2, *}$
}

\begin{abstract}
${ }^{I}$ European Institute, London School of Economics and Political Science, Room 1.12, Cowdray House (COW), Portugal Street, London, WC2A 2AE, United Kingdom.

${ }^{2}$ Amsterdam School of Economics and ACES, Amsterdam Centre for European Studies, Room 3.54, Roetersstraat 11, 1018WB Amsterdam, The Netherlands.
\end{abstract}

\begin{abstract}
This paper examines the impact of rebalancing the policy mix away from monetary towards fiscal stimulus in the Euro zone, achieved at the supranational level by introducing a safe asset together with fiscal capacity at the centre. The model used is consensus Mundel-Fleming for a two-country ('core' and 'periphery') closed economy adapted to the critical features of Europe's Economic and Monetary Union. Specifically, alongside the determination of output, inflation and trade, the determination of financial flows and yields is explicitly modelled while the internal nominal exchange rate is fixed. Simulations are run in which a safe asset - dubbed Eurobond - replaces national bonds on banks and central bank's balance sheets, and a fiscal capacity at the center with the power to adjust the aggregate fiscal stance is introduced. Moreover, a new quantitative easing scheme, mandating the European Central Bank to adjust its portfolio of Eurobonds as deemed necessary in the pursuit of price stability, is introduced. The main conclusion emerging from the simulations is that had a Eurobond/fiscal capacity existed at the onset of the Great Financial Crisis, the recession would have been much more muted, and with much less need for unconventional monetary policy.
\end{abstract}

Keywords: European Monetary Union, business fluctuations, fiscal policy, monetary policy.

JEL Classification: E32, E63, F33

\section{INTRODUCTION}

The recovery of the Eurozone economy from the almost fatal sovereign debt crisis a decade ago relied on massive purchases of financial assets, predominantly national sovereign bonds, by the European Central Bank (ECB) alongside the provision of emergency loans to distressed governments conditional on harsh fiscal consolidation ('economic adjustment programmes'). While seen as vital at the time, this policy trajectory has resulted in new vulnerabilities, exposing the economy to reversals in financial conditions when new shocks hit, resulting in renewed calls on monetary policy ease.

Rebalancing the policy mix away from monetary towards fiscal stimulus an hardly be achieved at the national level due to a legacy of high public debt in several member states and ideological priors against discretionary fiscal policy in others. Hence a call would need to be made on supranational fiscal instruments. However, the political hurdles that the creation of new fiscal instruments at the supranational level would have to cross are also daunting. If at all, it can only be

\footnotetext{
*Address correspondence to this author at Amsterdam School of Economics and ACES, Amsterdam Centre for European Studies, Room 3.54, Roetersstraat 11, 1018WB Amsterdam, The Netherlands; Tel. +31 6243386 81; E-mail: p.j.vandennoord@uva.nl
}

achieved if seen as welfare-enhancing by all. As a minimum, for the 'core' member states to commit to such a change in policy would have to involve a reduction (rather than an increase) in 'moral hazard'. For the 'periphery' member states to commit, it would have to involve some form of risk sharing. And, in any case, it would have to contribute to the resilience of the Eurozone economy as a whole. Is it feasible to combine this set of conditions in an overarching approach? This paper provides evidence that this might be the case and on how this may be achieved.

\section{THE PROPOSAL}

In a monetary union, all participating governments must behave responsibly for reasons that mostly pertain to crossborder spill-over effects and the externalities of financial instability, see e.g. Beetsma and Giuliodori (2010). Therefore, irresponsible behavior must be discouraged. Several periphery members of the European Economic and Monetary Union (EMU) learned this the hard way during the financial and sovereign debt crises, especially those that enrolled in an economic adjustment programme.

Even so, the experience has shown also that countries that are "too big to fail" may get away with a more lenient treatment. Specifically, Italy miraculously escaped enrolment in an economic adjustment programme, as ECB President's Draghi's "whatever it takes" statement in July 2012 and the 
ensuing Outright Monetary Transactions (OMT) and Asset Purchase Programmes contributed to reducing its sovereign yields. As a result, the pressure eased on the Italian government to put fiscal policy on a sustainable path, pursue ambitious structural reforms and tackle the non-performing loans problem of its banks decisively.

This state of affairs is obviously a bone of contention for the northern Eurozone members. It frustrates any initiative to share financial and macroeconomic risk in the Eurozone ex ante. Earlier proposals to do so, including the establishment of a Eurozone fiscal capacity, a Eurozone single bond (or 'safe asset'), and completion of the Banking Union (e.g. a single deposit insurance and a single resolution fund backstopped by the joint sovereigns), never went very far.

In the absence of such ex ante risk-sharing mechanisms, the ECB is bound to continue to act as a backstop for national sovereigns via its Asset Purchase programme. Without these, sovereign yields in 'periphery' countries - notably in Italy would likely rebound, and their banks default as their cost of funding would soar given their large exposure to national sovereigns. This has prompted northern ('core') member states to call for the abolition of zero-risk weights of sovereigns on banks' balance sheets as a condition sine qua non for completion of the banking union, but - while this makes sense in the long run (and indeed is part of our proposal below) - it would likely require even more monetary accommodation to offset the resulting adverse shock on banks in the periphery during the transition.

The critical elements of our proposals as such are not new (see for a review of reform proposals Codogno and Van den Noord, 2019). However, as far as we can tell, ours is the first to encompass these critical elements in a single reform proposal. It is three-pronged:

1. A new safe asset, dubbed Eurobond, is issued at the centre by a new fiscal capacity, with a joint guarantee by Eurozone countries. It is swapped, on a voluntary basis, at market prices for national sovereigns on the balance sheets of banks and the ECB. It thus replaces the national sovereign bonds in their role as collateral for banks in repos and inter-bank loans. The Eurobond enjoys exclusive eligibility to ECB asset purchases and replaces the national sovereign bond of the core as the risk-free benchmark. The zero-risk weight for national sovereign bonds is abolished, to ensure that the Eurobond (which would receive a zero-risk weight) is seen as an attractive investment while absorbing minimal capital. The profit banks generate by the sale of sovereign bonds is allowed to be spread over several years to smooth the transition to a bank business model that no longer relies on carry trades with sovereign bonds and to allow sufficient time for banks to achieve higher profitability from other sources. The ECB would allow banks to close in advance their financing operations to offset the selling of national sovereign bonds on their balance sheet.

2. The replacement of national sovereigns by Eurobonds on banks' balance sheets serves to break the 'doom loop' between the cost of bank funding and sovereign yields. As a result, the funding cost for banks, notably in the periphery, would fall, and the interbank market would recover. Moreover, since Eurobonds enjoy exclusive eligibility to asset purchases by the ECB, they provide the ECB with a handle on the lending channel without interference with national fiscal policies via national sovereign debt purchases. Since national sovereigns lose their eligibility to ECB asset purchase, market forces will discipline fiscal behavior in the periphery more than in the present situation where asset purchases provide protection. We acknowledge the possibility that the weighted interest rate cost for national sovereigns of the combination of Eurobonds and national bonds may be higher than the current situation due to the convexity of the credit curve. However, this would be a desirable development as it would provide additional incentives to governments to keep their public finances in order.

3. Alongside the issuance of Eurobonds to purchase national sovereigns, the fiscal capacity may issue Eurobonds to finance deficit spending at the centre. It could take the form of automatic stabilisers' (with for instance unemployment insurance) or discretionary spending on projects that transcend national interests (climate policy, public infrastructure, or more topical at present - combatting pandemics). As this results in an easing of the aggregate fiscal policy stance, Eurobond yields may increase (everything else equal). However, the ECB would be allowed to purchase Eurobonds to keep yields in check, so de facto acting as a backstop. It would underpin the Eurobond's role as the (new) safe asset, with a liquid risk-free benchmark yield, for the Eurozone.

Since Eurobonds are underpinned by a guarantee by the joint national sovereigns and also eligible to quantitative easing conducted by the ECB, they would become genuinely riskfree, akin to US Treasury notes. Hence their yields would be determined by current and (expected) future monetary policy along with a term premium. Quantitative easing would become a genuine monetary policy instrument, unlike the blend of fiscal and monetary policy goals it currently pursues. Fiscal policy by the Eurozone fiscal capacity would be its natural complement, with the supranational fiscal deficit funded by the issuance of Eurobonds and its repayment secured by its own tax base and/or mandatory contributions by the national sovereigns.

A fundamental assumption is that the Eurozone fiscal capacity issues Eurobonds initially to purchase national sovereigns in the hands of the ECB (according to its asset purchase programme) and on the balance sheets of the banks. The total amount involved is roughly $30-40 \%$ of GDP. To the extent that sovereign bond holdings of banks differ across countries as a share of their GDP, extra amounts of these bonds need to be purchased in the secondary market against the issuance of new Eurobonds to make up for these differences. To allow proper price discovery, a sizeable enough new issuance of Eurobonds will precede the swap operation. The yields on 
national sovereigns will not be affected at this stage, and initially, the yield on the Eurobond would approximately be the weighted average of the yields on the national sovereigns, with the weights corresponding to the capital key.

At the national level, the incentives facing governments - as noted - change. Suppose that an adverse shock hits the economy. In the current situation, the ECB would purchase more national sovereigns, which - even if the ECB respects the capital key - works more to the advantage of the periphery, providing fiscal space they could use for stimulus, which is, inevitably, a source of moral hazard. However, in the new set-up, the ECB can only buy Eurobonds. Given that the Eurobond yield serves as the benchmark, it would reduce the yields on national sovereigns, but without affecting the spread between periphery and core sovereign yields. It would strengthen market discipline on periphery bonds so that national fiscal policy in the periphery would be more restrained than otherwise. Instead, supranational fiscal policy could kick in, if need be, with support from quantitative easing (QE). This new form of QE, by contrast, does not entail moral hazard for national sovereigns.

\section{MODELLING THE MACROECONOMIC IMPACT}

In an earlier paper (Codogno and Van den Noord 2019) we examined how the above new set of policy tools could improve the resilience of the Eurozone economy to (symmetric or asymmetric) demand and supply shocks. In this paper, we extend this analysis to include financial risk-premium shocks stemming from, for example, deterioration of asset quality in periphery banks, political turmoil in the periphery or a fall in global risk appetite. This broader analysis necessitated a major extension of our stylised macroeconomic model, to include an explicit modelling of bond yields, bank lending and public debt dynamics.

While this model is necessarily a simplification, we think it captures essential features of the EMU. It distinguishes two economies, 'core' and 'periphery', with the latter prone to financial instability due to high public debt - much of it owned by local banks alongside other assets (loan books) whose quality is (also) questionable - which gives rise to adverse feedback loops between weak fiscal positions and weak banks. This is a significant parametric asymmetry built into the model alongside other asymmetries, such as a greater inflation-proneness in the periphery (even if most of the countries at the periphery stayed well below the ECB's definition of price stability since the launch of EMU).

Our model is best described as a consensus Mundel-Fleming model for a two-country closed economy, adapted to what we consider to be the most critical features of EMU. This implies that the determination of output, inflation and trade is explicitly modelled alongside the determination of financial flows and yields, while the nominal exchange rate is (irrevocably) fixed. The parameters are calibrated on the basis of empirical findings in the mainstream literature on EMU.

Starting off from a baseline version of the model describing the current situation, we modify it to introduce: (i) a single Eurobond to replace national bonds on banks' and the ECB's balance sheets, with the Eurobond enjoying a better credit standard than national sovereign bonds issued in the periphery; (ii) a Eurozone fiscal capacity with power to adjust the aggregate fiscal stance in the pursuit of macroeconomic stabilisation; and (iii) a new quantitative easing scheme mandating the ECB to adjust its portfolio of Eurobonds as needed in the pursuit of price stability. Unless stated otherwise, all variables are defined in terms of their deviations from a baseline in which all shock variables are nil.

We will first discuss the section of the model concerning the real economy, and then move on to the financial sector and the government sector, with macroeconomic policy at that stage still exogenous. Finally, we derive optimal monetary and fiscal policy rules, including fiscal policy at the centre, and solve for (Nash) equilibrium.

\subsection{Thereal Economy}

The aggregate (log-linear) demand equations follow the standard Mundell-Fleming approach adapted to the features of a (closed) monetary union with credit-constrained households and businesses and are perfectly symmetric:

$$
\begin{aligned}
& y^{d}=\phi_{1} l+\phi_{2}\left(f+s f^{\epsilon}\right)-\phi_{3}\left(\pi-\pi^{*}\right)-\phi_{4}\left(y-y^{*}\right)+\varepsilon^{d} \\
& y^{* d}=\phi_{1} l^{*}+\phi_{2}\left(f^{*}+s f^{* \epsilon}\right)-\phi_{3}\left(\pi-\pi^{*}\right)-\phi_{4}\left(y-y^{*}\right)+\varepsilon^{* d}
\end{aligned}
$$

where an asterisk $(*)$ indicates the periphery, and variables without an asterisk refer to the core. Aggregate demand $y^{d}$ and $y^{* d}$ is determined by the supply of bank credit $l$ and $l^{*}$, the fiscal stance - gauged by the primary government deficit $f$ and $f^{*}-$ and cross-border trade. The latter is a function of the inflation differential $\pi-\pi^{*}$ (a proxy for the real exchange rate) and the relative pace of economic growth $y-y^{*}$ to capture the income effect on trade. In addition, we include the impact of fiscal policy conducted by the 'fiscal capacity', captured by its primary deficit as distributed to each block, denoted as $f^{\epsilon}$ and $f^{*} \in$. Throughout the model, we use a dummy variable that takes the value $s=0$ in the current situation and $s=1$ once the fiscal capacity has been created. For simplicity, the multipliers for national and supranational fiscal policy are assumed to be the same (i.e. $\left.\phi_{2}\right)$. Finally, $\varepsilon^{d}$ and $\varepsilon^{* d}$ are demand shocks.

Aggregate supply $y^{s}$ and $y^{* s}$ is determined by the inflation 'surprises' $\pi-\pi^{e}$ and $\pi^{*}-\pi^{* e}$ relative to expectations (denoted by the superscript $e$ ) alongside exogenous supply shocks $\varepsilon^{s}$ and $\varepsilon^{* s}$, via an inverted Phillips-curve:

$$
\begin{aligned}
& y^{s}=\left(\pi-\pi^{\epsilon}\right) / \omega+\varepsilon^{s} \\
& y^{*_{s}}=\left(\pi^{*}-\pi^{* \epsilon}\right) / \omega+\varepsilon^{*_{s}}
\end{aligned}
$$

Expected inflation is partly anchored in the official inflation target $\bar{\pi}^{T}$ and is partly backward looking and hence depends on actual domestic inflation: 
$\pi^{\epsilon}=(1-\eta) \bar{\pi}^{T}+\eta \pi$

$\pi^{* \in}=\left(1-\eta^{*}\right) \bar{\pi}^{T}+\eta^{*} \pi^{*}$

Since all variables are defined as deviations from a steady state in which all shocks are nil, we may assume that $\bar{\pi}^{T}=0$. We allow for the possibility of an asymmetry in the formation of inflation expectations such that $\eta^{*} \geq \eta$, which means that potentially there could be greater inflation proneness in the periphery than in the core.

Finally, in equilibrium aggregate demand equals aggregate supply, hence:

$$
\begin{aligned}
& y^{s}=y^{d}=y \\
& y^{* s}=y^{* d}=y^{*}
\end{aligned}
$$

The numerical calibration of the parameters is displayed in Table 1. A crucial parameter is $\phi_{1}$, capturing the impact of bank credit on the real economy. There are not many estimates for it available in the literature. Antoshin et al. (2017) find for 39 European countries a 10 percent increase in bank credit to boost real GDP by $0.6-1 \%$. However, Cappiello et al. (2010) find a much stronger effect for a panel of Eurozone members, with a $10 \%$ increase in credit leading to a $3.2 \%$ increase in real GDP. Accordingly, we adopt $\phi_{1}=0.333$.

For the other parameters in equations (1) we resort to the numerical calibration in Codogno and Van den Noord (2019). Accordingly, for the fiscal multiplier $\phi_{2}$ we adopt a value of 0.5 , which is in the ballpark of estimates by Baum et al. (2012) and Barrell et al. (2012). Estimates for the parameters that capture cross-border trade, comprising $\phi_{3}$ for absorption and $\phi_{4}$ for competitiveness, are based on Bayoumi et al. (2011) and ECB (2013), with $\phi_{3}=\phi_{4}=0.5$.

For the parameter gauging the slope of the Phillips curve $\omega$ we again refer to Codogno and Van den Noord (2019), who-based on Ball et al. (2013) and Llaudes (2005) -assumed that $\omega=0.25$. Finally, Van der Cruijsen and Demertzis (2009) find a strong dependence of inflation expectations on actual inflation in the periphery, but no such relationship in the core. Therefore, we will adopt as our baseline estimate $\eta=0$ and $\eta^{*}=0.5$.

\begin{tabular}{|c|c|c|c|c|c|c|c|c|c|c|}
\hline \multicolumn{2}{|c|}{ Real Economy } & \multicolumn{4}{|c|}{ Financial Sector } & \multicolumn{2}{|c|}{ Government Sector } & \multicolumn{3}{|c|}{ Policy Reaction Functions } \\
\hline$\phi_{1}$ & 0.333 & $\xi_{1}$ & 3.000 & $\vartheta_{1}$ & 0.500 & $\tau$ & 0.500 & $\alpha$ & 1.282 & 0.218 \\
\hline$\phi_{2}$ & 0.500 & $\xi_{2}$ & 0.130 & $\vartheta_{2}$ & 0.050 & $\theta$ & 0.250 & $\beta$ & 0.005 & 0.001 \\
\hline$\phi_{4}$ & 0.500 & $\xi_{1}^{*}$ & 3.000 & $\vartheta_{1}^{*}$ & 0.500 & $b_{0}$ & 0.500 & $\gamma^{*}$ & 0.052 & 0.180 \\
\hline$\eta$ & 0.000 & $\xi_{2}^{*}$ & 0.250 & $\vartheta_{2}^{*}$ & 0.100 & $b_{0}^{*}$ & 1.300 & $\delta$ & & 0.397 \\
\hline$\eta^{*}$ & 0.500 & $\xi_{3}^{*}$ & 4.500 & $\vartheta_{3}^{*}$ & 0.260 & $b_{0}^{\epsilon}$ & 0.400 & & & \\
\hline
\end{tabular}

Table 1. Numerical Calibration.

Sources: See main text.

\subsection{The Financial Sector}

A hallmark of the Eurozone predicament is the so-called 'doom loop' which refers to tensions in the sovereign debt market prompting a 'credit crunch', with the resulting economic slump feeding back into the sustainability of sovereign debt. The main channel through which tensions in sovereign debt markets affect the supply of bank credit is via the cost and the availability of wholesale funding for banks. Financial distress and the associated capital flight from the periphery to core sovereign debt raise the cost and cut the availability of funding for banks in the periphery.

It may be assumed that this source of vulnerability vanishes once Eurobonds, guaranteed by the joint sovereigns, become available. As the national sovereign will lose their eligibility for purchases by the ECB, and Eurobonds would be eligible instead, national sovereigns would become inherently riskier. It, therefore, makes sense that they would also lose their zero-risk weighting. Therefore, it is reasonable to assume that banks agree to swap their sovereign debt portfolio for Eurobonds, on a voluntary basis. As a result, sovereign debt distress, and the associated capital flight from the periphery to the core, no longer matters for the cost or availability of bank funding in the periphery.

Moreover, since all banks have access to the same safe asset, the Eurobond, central bank purchases can be assumed to induce banks to convert the additional (excess) reserves thus created into loans (unlike the current situation where banks 
keep the excess on their balance sheets as protection against loss of access to wholesale funding). This is known in the literature as the direct bank lending channel of quantitative easing. Evidence of this channel being effective at present in the Eurozone is weak, as banks in practice have been holding on to their excess reserves or used them to pay down external funding or (re-)purchase debt securities instead of providing credit to the economy (see Ryan and Whelan, 2019). However, this may change when banks are induced to hold Eurobonds in lieu of national sovereign bonds. As national sovereign bonds lose their zero-risk weighting, the scope for carry trades diminishes and, with the 'doom loop' broken, the need to hold on to excess reserves also diminishes, hence it looks plausible that a direct bank lending channel will open. There is indeed some empirical evidence that a direct bank lending channel is effective in cases where banks have access to a (national) safe bond, see Paludkiewicz (2018) for Germany, Joyce and Spaltro (2014) for the UK and Kandrac and Schlusche (2018) for the US.1

These notions are embedded in the following stylized (loglinear) equations for bank credit measured as a percentage of nominal output, in which the periphery-core yield spread $r^{*}-r$ is included as a gauge of sovereign debt distress:

$$
\begin{aligned}
& l-(y+\pi)=-\xi_{1} i+s \xi_{2} q-(1-s) \xi_{3}\left(r-r^{*}\right)+\lambda \\
& l^{*}-\left(y^{*}+\pi^{*}\right)=-\xi_{1}^{*} i+s \xi_{2}^{*} q-(1-s) \xi_{3}^{*}\left(r^{*}-r\right)+\lambda^{*}
\end{aligned}
$$

and where $\lambda$ and $\lambda^{*}$ are exogenous shocks to the respective banking systems (credit crunch or credit boon). Moreover, $q$ denotes the purchases of sovereign bonds by the ECB as a percentage of GDP, and $i$ is the ECB's main policy rate (for simplicity we abstract from the distinction between the deposit and the repurchase rate). We expect that $\xi_{1}^{*} \geq \xi_{1}$, $\xi_{2}^{*} \geq \xi_{2}$ and $\xi_{3}^{*} \geq \xi_{3}$, so generally speaking the sensitivity of bank lending to monetary policy and financial market distress would be larger in the periphery than in the core. Note also that there is an asymmetry in the sense that the adverse effect of the yield spread on lending in the periphery has the opposite sign of the safe-haven effect on lending in the core, and that both tend to widen the differential. Specifically, in the current situation where $s=0$ the differential between bank lending in the periphery and the core is determined as:

$$
\begin{aligned}
& {\left[l^{*}-\left(y^{*}+\pi^{*}\right)\right]-[l-(y+\pi)]=} \\
& -\left(\xi_{1}^{*}-\xi_{1}\right) i-\left(\xi_{3}^{*}+\xi_{3}\right)\left(r^{*}-r\right)+\left(\lambda^{*}-\lambda\right)
\end{aligned}
$$

1 To be fair, Rodnuansky and Darmouni (2017) find no evidence of a direct bank lending channel for the US (except for purchases of mortgage backed securities) and similarly Buttz et al (2015) for the UK. Fatouh et al (2019) even observe a decline in bank lending in the UK as large corporate borrowers turned to the corporate bond market were yields had fallen in response to $\mathrm{QE}$ (though arguably this is a demand effect and not a supply effect on bank loans).
This implies that a priori changes in financial conditions such as increases in the official policy rate and sovereign debt distress tend to widen the differential in the incidence of lending at the detriment of the periphery. Quantitative easing (asset purchases by the ECB) kicks in via its impact on the yield spread (see below). However, if $s=1$, we get:

$\left[l^{*}-\left(y^{*}+\pi^{*}\right)\right]-[l-(y+\pi)]=-\left(\xi_{1}^{*}-\xi_{1}\right) i+$

$\left(\xi_{2}^{*}+\xi_{2}\right) q+\left(\lambda^{*}-\lambda\right)$

the yield spread $r^{*}=r$ disappears from the equation while quantitative easing now kicks in via the direct bank lending channel.

This takes us to the determinants of the sovereign yield spread of the Eurozone periphery against the core $r^{*}=r$. There is a burgeoning literature on the sovereign yield spread in the Eurozone, which is usually assumed to be driven by country-specific liquidity risk, country-specific default risk and the risk appetite of global investors (see, for instance, Codogno et al. 2003). The ratio of sovereign debt to GDP (alongside the fiscal deficit feeding into the debt ratio) is usually considered to be the main driver of country-specific default risk. As several studies have shown, the relationship between debt and spread can be strongly non-linear and dependent on global risk sentiment. With the outbreak of the global financial crisis, the perception of higher sovereign default risks produced a sharp increase in yield spreads, and even more so in countries whose initial debt ratio was comparatively high.

By contrast, as indicated inter alia by De Grauwe and $\mathrm{Ji}$ (2012), in developed economies with a federal/central government who issues debt in its 'own' currency, federal sovereign yields tend to incorporate liquidity and exchange rate risk premiums, but not a default risk premium. A Eurobond, issued by an appointed fiscal capacity with full democratic legitimacy, and which enjoys a joint guarantee by the national sovereigns, may be assumed to broadly fit this description. However, once a Eurobond exists, the national sovereigns would become more akin to state and local government debt in federal states, i.e. would still carry default risk premia (see Schuknecht et al., 2009). In fact, due to the joint guarantee (and assuming this guarantee is credible), national sovereign debt would become inherently riskier than at present, with their yields incorporating risk premia not only for national but also for supra-national public debt.

These features are reflected in the following set of equations for national and supranational yields:

$$
\begin{aligned}
& r=s r^{\epsilon}+(1-s)\left(g_{1} i-g_{2} q\right)+g_{3}\left(b+s b^{\epsilon}\right)+\rho \\
& r^{*}=s r^{\epsilon}+(1-s)\left(g_{1}^{*} i-g_{2}^{*} q\right)+g_{3}^{*}\left(b^{*}+s b^{€}\right)+\rho^{*}(6) \\
& r^{\epsilon}=(1-s) \frac{1}{2}\left(r+r^{*}\right)+s\left(\sigma_{1} i-\sigma_{2} q+\rho^{\epsilon}\right)
\end{aligned}
$$

where $r, r^{*}$ and $r^{\epsilon}$ are the yields on core, periphery and supranational sovereign debt and $b, b^{*}$ and $b^{\epsilon}$ denote the corresponding sovereign debt as a per cent of GDP. The var- 
iables $\rho, \rho^{*}$ and $\rho^{\epsilon}$ are exogenous risk premium shocks. Moreover, $q$ again denotes the purchases of sovereign bonds (regardless of the issuer) by the ECB, as a percentage of GDP, and $i$ is again the ECB's main policy rate. We expect $g_{1}^{*} \geq g_{1}, g_{2}^{*} \geq g_{2}, g_{3}^{*} \geq g_{3}$, so generally speaking periphery yields are the most sensitive to developments in sovereign debt and monetary policy. Let us recall that all variables (except for the dummy $s$ ) are defined in terms of deviations from a baseline in which all shock variables are nil.

If $s=0$ (i.e. the current situation without a Eurobond), the sovereign yield spread in this specification is determined by the impact of monetary policy (both conventional and nonconventional) and the development of national sovereign debt. Formally, the Eurobond yield would be a synthetic yield computed as the average of the national yields, but there would not be any Eurobonds circulating:

$$
\begin{aligned}
& r^{*}-r=\left(\vartheta_{1}^{*}-\vartheta_{1}\right) i-\left(\vartheta_{2}^{*}-\vartheta_{2}\right) q+\left(\vartheta_{3}^{*}-\vartheta_{3}\right) b^{*}+\vartheta_{3}\left(b^{*}-b\right) \\
& +\left(\rho^{*}-\rho\right) r^{\epsilon}=\frac{1}{2}\left(r+r^{*}\right)
\end{aligned}
$$

By contrast, if $s=1$ (i.e. with a Eurobond), the national sovereign yields are determined by their spreads against the new benchmark (the Eurobond), in turn, affected by developments in both the national and supranational debt ratios (the latter due to the guarantee). As a result, the impact of monetary policy on the national sovereign yields is now indirect, i.e. via its impact on Eurobond yields:

$$
\begin{aligned}
& r-r^{\epsilon}=\vartheta_{3}\left(b+s b^{\epsilon}\right)+\rho \\
& r^{*}-r^{\epsilon}=\vartheta_{3}^{*}\left(b^{*}-s b^{\epsilon}\right)+\rho^{*} \\
& r^{\epsilon}=\sigma_{1} i-\sigma_{2} q+\rho^{\epsilon}
\end{aligned}
$$

The numerical assumptions for the system of equations (5) and (6) are again as much as possible based on the mainstream literature (see Table $\mathbf{1}$ ).

For bank lending, Albertazzi et al. (2012), find for Italy (which we take to represent the periphery) an adverse effect of a100bps increase in the spread $r^{*}=r$ of the order of $3.5 \%$ for loans to NFCs and $6.0 \%$ for household loans. Given the relative weights of NFC and household loans, this implies that approximately $\xi_{3}^{*}=4.5$. Based on the same study we adopt $\xi_{1}^{*}=3.5$ for the impact of the policy rate on bank credit, although estimates were based on the peak of the government bond crisis and by now the sensitivity has decreased significantly. In the core, we assume the impact of the spread $r^{*}=r$ to be nil such that $\xi_{3}=0$, as suggested by Altavilla et al. (2016). For the impact of quantitative easing on bank lending we adopt $\xi_{2}^{*}=0.25$, i.e. for every euro liquidity created on banks' balance sheets in the periphery through asset purchases, one-quarter is converted into bank loans. This is in line with findings for the United Kingdom reported by Joyce and Salto (2014). Our baseline assumption for the effectiveness of quantitative easing in the core is smaller than in the periphery, with $\xi_{2}=0.125$, to reflect the smaller holdings of sovereigns on banks' balance sheets.

The numerical calibration of the yield equations is based on De Santis (2016). Accordingly, we adopt for the impacts on yields of the policy rate $\vartheta_{1}=\vartheta_{2}^{*}=0.5$, with the impact thus less than proportional to reflect that tighter monetary policy now gets countries loser monetary policy later, so bond yields will not increase as much as policy rates. With regard to the impact of quantitative easing on sovereign yields we adopt $\vartheta_{2}=0.05$ and $\vartheta_{1}^{*}=0.1$. This implies that for every $1 \%$ of GDP equivalent of asset purchases by the ECB, yields would drop by 5 basis points in the core and by 10 basis points in the periphery. Note that total asset purchases by the ECB to date have roughly amounted to around $25 \%$ of GDP, which according to the above estimates would have slashed yields by 100 basis points in the core and 250 basis points in the periphery. Finally, based on the same study, we adopt for the impact of the public debt ratio on the sovereign yields $\vartheta_{3}=0.23$ and $\vartheta_{3}^{*}=0.26$.

Obviously, we do not know how the yield on Eurobonds will behave in response to monetary policy. Therefore, we will simply assume the impact of ECB asset purchases on the Eurobond yield to average that on the national sovereign yields when $s=0$, so $\sigma_{1}=0.5$ and $\sigma_{2}=0.075$.

\subsection{The Government Sector}

We also need a set of identities to determine the evolution of the public debt ratios to GDP (national and supranational) as well as the respective primary deficits. The usual debt dynamics identities capture the evolution of the debt ratio to output at the national and supranational levels:

$$
\begin{aligned}
& b=b_{0}(\chi r-y-\pi)+f \\
& b^{*}=b_{0}^{*}\left(\chi r^{*}-y^{*}-\pi^{*}\right)+f^{*} \\
& b^{\epsilon}=s b_{0}^{\epsilon}\left(\chi r^{\epsilon}-\bar{y}-\bar{\pi}\right)+\frac{1}{2}\left(f^{\epsilon}+f^{*^{\epsilon}}\right)
\end{aligned}
$$

Where $\bar{\pi}={ }_{2}^{1} \pi+{ }_{2}^{1} \pi^{*}$ and $\bar{y}={ }_{2}^{1} y+{ }_{2}^{1} y^{*}$. Let us recall that $f$, $f^{*}, f^{\in}$ and $f^{*} \in$ denote the respective primary deficits as a ratio to output that enters the system of aggregate demand equations (1) and that $b_{0}, b_{0}^{*}$ and $b_{0}^{\in}$ are the respective "initial" debt ratios, whereby we mean the prevailing debt ratios if none of the potential demand, supply or financial shocks occur (i.e. $\varepsilon^{d}=\varepsilon^{* d}=\varepsilon^{s}=\varepsilon^{* s}=\lambda=\lambda^{*}=\rho=\rho^{*}=0$ ). As before, if $s=0$ no Eurobonds are created, so $b^{\in}=0$. However, if $s=1$, the debt ratio would change in response to variations in the relevant yields, economic growth and inflation alongside the conduct of fiscal policy at the centre. We make a simplifying assumption that a fraction $\chi$ of the changes in yields feed through in the implicit debt servicing cost, depending on the percentage of the total stock of debt that comes due each year. In the model simulations, it is assumed that $\chi=0.2$. 
The primary fiscal deficits $f, f^{*}, f^{\epsilon}$ and $f^{*} \in$ are partly endogenous on account of 'automatic stabilisers' (e.g. variations in tax proceeds or social security outlays as a function of cyclical economic activity), so they comprise induced and discretionary components:

$$
\begin{aligned}
& f=-(\tau-s \theta) y+g, f^{\epsilon}=-s \theta y+g^{\epsilon} \\
& f^{*}=-(\tau-s \theta) y^{*}+g^{*}, f^{\epsilon^{*}}=-s \theta y^{*}+g^{\epsilon}
\end{aligned}
$$

where $g, g^{*}$ and $g^{\epsilon}$ denote the stance of the discretionary component of the fiscal respective deficits and $\tau$ corresponds to the usual "semi-elasticity" of the fiscal deficit with respect to output. In this specifications $\theta$ takes a positive value when a supra-national fiscal capacity is created, and certain tax or spending programmes are reallocated to it, and nil otherwise. The primary deficit at the central level is simply the average $\bar{f}^{\epsilon}={ }_{2}^{1} f \in+{ }_{2}^{1} f \epsilon^{* *}$.

For the numerical calibration of the automatic stabilization effect, we refer to Van den Noord (2000) and Girouard and André (2005), which implies that $\tau=0.5$. Furthermore, we assume that $b_{0}=50 \%, b_{0}^{*}=130 \%$ and $b_{0}^{\epsilon}=40 \%$. This roughly corresponds to, respectively, the public debt to GDP ratios in Germany and Italy and the amount of Eurobonds that approximately needs to be issued to cover the purchases of national sovereigns on the balance sheets of the ECB and the banks as well as any additional purchases in the market needed to secure consistency with the capital key. As concerns the parameter $\theta$ we refer to Van den Noord (2019, 2020), who assumes that half of the automatic stabilization effect would accrue to the centre, so if $\tau=0.5$ then $\theta=0.25$.

\subsection{Policy Reaction Functions and Nash Equilibrium}

We will assume that monetary and fiscal policies are geared towards their respective macroeconomic stabilisation goals: aggregate inflation $\bar{\pi}={ }_{2}^{1} \pi+{ }_{2}^{1} \pi^{*}$ in the case of monetary policy, national output $y$ and $y^{*}$ in the case of national fiscal policies and aggregate output $\bar{y}={ }_{2}^{1} y+{ }_{2}^{1} y^{*}$ in the case of supranational fiscal policy. The respective authorities are assumed to minimise the welfare loss gauged by the squared deviations from equilibrium, taking into consideration also the welfare losses that may stem from socially or politically costly swings in their policy instruments and that motivate inertia in the conduct of policy.

Accordingly, the ECB faces the following welfare loss minimisation problem:

$$
\min _{q, i} L_{\bar{\pi}}=\frac{1}{2} \bar{\pi}^{2}+\alpha \frac{1}{2} i^{2}+\beta \frac{1}{2} q^{2}(9)
$$

where $\alpha$ and $\beta$ represent the social cost of conventional and non-conventional monetary policy relative to the cost of missing the inflation target. The first-order conditions in (9) imply that:
$\Omega_{i}^{\bar{\pi}} \bar{\pi}+\alpha i=0, \Omega_{q}^{\bar{\pi}} \bar{\pi}+\beta q=0(10)$

Where $\Omega_{i}^{\bar{\pi}} \equiv \frac{\partial \bar{\pi}}{\partial i} \quad$ and $\quad \Omega_{q}^{\bar{\pi}} \equiv \frac{\partial \bar{\pi}}{\partial q}$ represent the shockresponse multipliers of conventional and non-conventional monetary policy on aggregate inflation $\bar{\pi}$ embedded in the system of equations (1)-(8). The solution for aggregate inflation is also derived from that system, and in short-hand notation reads:

$$
\bar{\pi}-\Omega_{i}^{\bar{\pi}} i+\Omega_{q}^{\bar{\pi}} q+\mathrm{Z}_{\bar{\pi}}(11)
$$

Where $Z_{\bar{\pi}}$ is the vector of impact responses of aggregate inflation with respect to all other policy and shock variables embedded in the system (1)-(8). Combining equations (10) and (11) then yields solutions for the monetary policy instruments $i$ and $q$.

The national governments minimise the welfare loss $L_{y}$ or $L_{y^{*}}$ associated with variations in their output gap (the deviation of output from steady state equilibrium). Fiscal policy is subject to inertia due to adjustment costs associated with a change in policy, so:

$$
\begin{aligned}
& \min _{g} L_{y}=\frac{1}{2} y^{2}+y \frac{1}{2} g^{2} \\
& \min _{g^{*}} L_{y^{*}}=\frac{1}{2} y^{* 2}+y^{*} \frac{1}{2} g^{* 2}
\end{aligned}
$$

where $y$ and $y^{*}$ represent the social cost of changing the budget, relative to the social cost of deviations from equilibrium output. The first-order conditions in (12) imply that:

$$
\Omega_{g}^{y} y+y g=0, \Omega_{g^{*}}^{y^{*}} y^{*}+y^{*} g^{*}=0
$$

with

$\Omega_{g}^{y} \equiv \frac{\partial y}{\partial_{g}}$ and $\Omega_{g^{*}}^{y^{*}} \equiv \frac{\partial y^{*}}{\partial_{g^{*}}}$ represent the shock-response multipliers of national fiscal policies on domestic output $y$ and $y^{*}$, respectively. The solutions for output $y$ and $y^{*}$ in shorthand notation read:

$$
y=\Omega_{g}^{y} g+Z_{g}, y^{*}=\Omega_{g^{*}}^{y^{*}} g^{*}+Z_{g^{*}}
$$

Where again $Z_{g}$ and $Z_{g^{*}}$ are the vectors of impact responses of domestic output with respect to all other policy and shock variables. Combining equations (13) and (14) then yields solutions for the national fiscal policy stances $g$ and $g^{*}$.

We will also consider the possibility that fiscal rules are binding in the periphery, such that the conduct of discretionary fiscal policy is committed to achieving a required 'fiscal 
effort', for instance, because the debt ratio exceeds the $60 \%$ of GDP benchmark (as is typically the case in the periphery). In that case, it is assumed that $g^{*}=0$.

Finally, fiscal policy at the supra-national level is assumed to be conducted according to the following welfare loss minimisation problem:

$$
\begin{aligned}
& s=0 \Rightarrow g^{\in}=0 \\
& s=1 \Rightarrow \underset{g^{\epsilon}}{\min L_{\bar{y}}}=\frac{1}{2} \bar{y}^{2}+\delta \frac{1}{2} g^{\in 2}
\end{aligned}
$$

where if $s=1$, the fiscal capacity faces a trade-off between minimizing the aggregate output gap and the socio-political cost of variations in the primary deficit. The first-order condition in (15) implies that:

$$
\Omega_{g^{\epsilon}}^{\bar{y}} \bar{y}+\delta g^{\epsilon}=0(16)
$$

with $\Omega_{g^{\epsilon}}^{\bar{y}} \equiv \frac{\partial \bar{y}}{\partial g^{\epsilon}}$ representing the shock-response multiplier of supranational fiscal policy on aggregate output $\bar{y}$. The solution for aggregate output in short-hand notation reads:

$$
\bar{y}=\Omega_{g^{\epsilon}}^{\bar{y}} g^{\epsilon}+Z_{g^{\epsilon}}
$$

Where again $\mathrm{Z}_{g^{\epsilon}}$ is the vector of impact responses of aggregate output with respect to all other policy and shock variables. Combining equations (16) and (17) then yields a solution for the supranational fiscal policy stance $g^{\in}$.

Once all policy reaction functions are known, we can solve the system for all goals and policy instruments (Nash equilibrium). However, before we can solve the system, we need to fix the numerical weights $\alpha, \beta, y, y^{*}$ and $\delta$ on the policy instruments in the welfare loss functions (9), (12) and (15). The approach adopted here is to assume that all policy instruments move halfway to their "optimum" stances required to fully achieve their policy goals (such as for instance achieving $\bar{\pi}=0$ in the case of monetary policy). In more detail, the adopted approach is as follows.

In general terms, the welfare minimisation problem for each policy instrument $x$ with regard to 'its' policy goal $y$ reads $\min _{x} L_{y}=\frac{1}{2} y^{2}+\alpha \frac{1}{2} x^{2}$. From the first order condition follows that $\Omega_{x}^{y} y+\alpha x=0$, subject to $y=\Omega_{x}^{y} x+Z_{x}$. The policy reaction function then reads $x=\Omega_{x}^{y} Z_{x} /\left(\Omega_{x}^{y 2}+\alpha\right)$ Without inertia in the instrument variables(i.e. $\alpha=0$ ), the optimal policy rule thus reads $\tilde{x}=-Z_{x} / \Omega_{x}^{y}$, which implies that $x=\Omega_{x}^{y 2} /\left(\Omega_{x}^{y 2}+\alpha\right) \mid \tilde{x}$. This means that the policy instrument $x$ is only partially adjusted to its 'optimal' stance $\tilde{x}$. Hence if we assume policy to move halfway its optimal stance, we get $\Omega_{x}^{y 2} /\left(\Omega_{x}^{y 2}+\alpha\right)=\frac{1}{2}$, and so $\alpha=\Omega_{x}^{y 2}$. This algorithm is used throughout this paper for all policy instruments. It implies that if $s=0, \alpha=1.282, \beta=0.005, y=0.925$ and $y^{*}=0.052$, and if $s=1$, that $\alpha=0.218, \beta=0.001$, $y=0.190, y^{*}=0.018$, and $\delta=0.397$.

Note that monetary policy inertia is much larger without a Eurobond/fiscal capacity than with it, and that the same holds for fiscal policy in the core. This is, in itself, an interesting finding. The intuition is that in the current situation a fiscal expansion in the core or a monetary expansion (conventional or non-conventional) carry large impact-response multipliers (a big bang for the buck) due to the dynamics inherent in the 'doom loop', whereas this would be much less the case once a Eurobond/fiscal capacity has been created.

\section{SHOCK RESPONSES}

The model set out above contains four sets of shock variables: demand shocks $\varepsilon^{d}$ and $\varepsilon^{* d}$, supply shocks $\varepsilon^{s}$ and $\varepsilon^{*}$, bank lending shocks $\lambda$ and $\lambda^{*}$, and sovereign risk premium shocks $\rho, \rho^{*}$ and $\rho^{\epsilon}$. The shock responses depend on the regime adopted: without Eurobond/fiscal capacity $s=0$ or with Eurobond/fiscal capacity $s=1$. In the latter regime, we also make a distinction between two cases in which fiscal policy in the periphery is unconstrained or constrained $\left(g^{*}=0\right)$. So, the total number of possible shock responses is very large, and it may be more useful to look at a limited number of subsets in which shocks are combined in a meaningful way. We look at three such subsets:

1. First, we simulate a scenario which broadly reflects the shocks that hit the Eurozone economy at the onset of the Financial Crisis in 2008-2009 and the ensuing Sovereign Debt Crisis. Accordingly, we assume a symmetric demand shock $\left(\varepsilon^{d}=\varepsilon^{* d}=-5 \%\right)$ combined with an adverse risk premium shock hitting the periphery $\left(\rho^{*}=2 \%\right.$ points).

2. Next, we simulate a scenario which broadly mimics the consensus view that economic slack in the periphery is mostly 'structural', although additionally, non-performing loans on periphery banks' balance sheets act as a drag on aggregate demand ('lagging periphery'). Accordingly, we simulate an adverse supply shock in the periphery $\left(\varepsilon^{*}=-5 \%\right)$ combined with an adverse bank lending shock in the periphery $\left(\lambda^{*}=-10 \%\right)$.

3. Finally, we simulate a scenario which broadly mimics the consensus view that the core has made major headway with structural reform (e.g. the Harz-II reforms in Germany) while its sovereigns attract safehaven investors ('leading core'). Accordingly, we simulate a favourable supply shock in the 
$\operatorname{core}\left(\varepsilon^{s}=5 \%\right)$, combined with a favourable risk premium shock in the core ( $\rho=-1 \%$-point).

\subsection{The Great Financial Crisis and its Aftermath}

From the simulation results reported in Table 2, the following broad picture emerges:

1. In the baseline simulation (without Eurobond/fiscal capacity, scenario I in Table 2), output is much harder hit in the periphery than in the core, notwithstanding the assumed symmetry of the demand shock. This is primarily due to the 'doom loop', with a collapse of bank lending combined with a substantial increase in periphery public debt and yields. Discretionary fiscal policy is eased in both in the core and the periphery, but much more so in the former in a context of much greater availability of fiscal space, though 'automatic stabilisers' do work their way through in the periphery. Monetary policy kicks in forcefully - both conventional and nonconventional - but cannot prevent a major economic slump.

2. Had a Eurobond/fiscal capacity existed (scenario IIA in Table 2), bank lending in the periphery would not have collapsed, fiscal stimulus at the centre would have provided a substantial demand offset, while the increase in public debt in the periphery would have been comparatively muted. Yet, periphery yields would have increased more strongly, and quantitative easing would have been much more modest. All this would have pleased policymakers in the core.

3. Had in addition fiscal policy in the periphery be constrained by the fiscal rules being binding (Scenario IIB in Table 2), the increase in public debt in the periphery would have been even smaller, though this comes at the expense of a slightly less favourable outcome for aggregate output despite a somewhat stronger fiscal expansion at the centre.

All in all, had a Eurobond/fiscal capacity existed at the onset of the Great Financial Crisis, the recession would have been much more muted, and conventional monetary and fiscal policies could have done most of the job of macroeconomic stabilisation without resorting massively to unconventional instruments and without sowing the seeds of sovereign debt and bank defaults.

Table 2. Shock-Responses -- the Great Financial Crisis and its Aftermath.

\begin{tabular}{|c|c|c|c|c|c|c|c|}
\hline & \multicolumn{3}{|c|}{ Fiscal Capacity/Eurobond } & & \multicolumn{3}{|c|}{ Fiscal Capacity/Eurobond } \\
\hline & \multirow{3}{*}{ No } & \multirow{2}{*}{\multicolumn{2}{|c|}{$\frac{\text { Yes }}{\text { Fiscal Rules Binding }}$}} & & \multirow{3}{*}{ No } & \multirow{2}{*}{\multicolumn{2}{|c|}{$\frac{\text { Yes }}{\text { Fiscal Rules Binding }}$}} \\
\hline & & & & & & & \\
\hline & & No & Yes & & & No & Yes \\
\hline \multicolumn{4}{|c|}{ Output } & \multicolumn{4}{|c|}{ Primary deficit } \\
\hline Core $(y)$ & -4.1 & -1.3 & -1.2 & Core $(f)$ & 6.3 & 3.3 & 3.1 \\
\hline Periphery $\left(y^{*}\right)$ & -6.7 & -1.1 & -1.5 & Periphery $\left(f^{*}\right)$ & 3.3 & 2.7 & 0.4 \\
\hline Aggregate $(\bar{y})$ & -5.4 & -1.2 & -1.3 & Central $\left(f^{\in}\right)$ & 0.0 & 2.2 & 2.4 \\
\hline \multicolumn{4}{|c|}{ Inflation } & \multicolumn{4}{|c|}{ Debt } \\
\hline Core $(\pi)$ & -1.0 & -0.3 & -0.3 & Core $(b)$ & 8.8 & 4.1 & 3.9 \\
\hline Periphery $\left(\pi^{*}\right)$ & -3.3 & -0.5 & -0.7 & Periphery $\left(b^{*}\right)$ & 17.0 & 5.5 & 3.7 \\
\hline Aggregate $(\bar{\pi})$ & -2.2 & -0.4 & -0.5 & Central $\left(b^{\in}\right)$ & 0.0 & 2.7 & 3.1 \\
\hline \multicolumn{4}{|c|}{ Yields } & \multicolumn{4}{|c|}{ Fiscal stimulus } \\
\hline Core $(r)$ & -0.4 & 0.1 & -0.2 & Core $(g)$ & 4.2 & 3.0 & 2.8 \\
\hline Periphery $\left(r^{*}\right)$ & 2.5 & 2.6 & 1.9 & Periphery $\left(g^{*}\right)$ & 0.0 & 2.5 & 0.0 \\
\hline Eurobond $\left(r^{\epsilon}\right)$ & 0.0 & -1.5 & -1.8 & Central $\left(g^{\in}\right)$ & 0.0 & 1.9 & 2.1 \\
\hline \multicolumn{4}{|c|}{ Bank credit } & \multicolumn{4}{|c|}{ Monetary policy } \\
\hline Core $(l)$ & 0.7 & 2.8 & 3.9 & Policy rate $(i)$ & -1.9 & -0.9 & -1.1 \\
\hline Periphery $\left(l^{*}\right)$ & -17.4 & 4.6 & 5.4 & Assets ( $q$ ) & 29.5 & 13.9 & 16.9 \\
\hline
\end{tabular}

Source: Authors' computations. 


\subsection{Lagging Periphery}

As noted, aside from the impact of the shocks at the onset of the Great Financial Crisis, it is a generally accepted view that the periphery suffers from a number of structural weaknesses. This is captured in our model as a combination of an adverse supply shock and an adverse bank lending shock in the periphery. From the simulation results reported in Table $\mathbf{3}$ emerges the following:

1. In the absence of a Eurobond/fiscal capacity (scenario I in Table 3), output developments in the periphery and core sharply diverge at the detriment of the former. Yields also diverge, with the peripherycore spread surging and periphery public debt strongly outpacing the core. Asset purchases by the ECB and fiscal expansion in the core (relative to a baseline in which the stance of fiscal policy may be structurally tight) may pick up some of the slack. However, the core suffers from adverse spill-over effects on output from the periphery, acting as a persistent drag on economic activity. The stance of monetary policy (conventional and nonconventional) is tight due to the inflationary impact of the adverse supply shock in the periphery.

2. With the creation of a Eurobond/fiscal capacity (scenario IIa in Table 3), the adverse spill-over effects on the core are largely neutralised, with the contraction in the periphery much smaller. A fiscal expansion at the centre picks up some of the slack while the contraction in bank credit in the periphery is much smaller as well, as is the yield spread.

3. The picture is somewhat less favourable fiscal policy in the periphery is constrained (scenario IIb in Table 3), without impetus onto activity from fiscal policy in the periphery. A somewhat stronger fiscal expansion at the centre provides only a partial offset.

Table 3. Shock-responses - Lagging Periphery.

\begin{tabular}{|c|c|c|c|c|c|c|c|}
\hline & \multicolumn{3}{|c|}{ Fiscal Capacity/Eurobond } & & \multicolumn{3}{|c|}{ Fiscal Capacity/Eurobond } \\
\hline & \multirow{3}{*}{ No } & \multirow{2}{*}{\multicolumn{2}{|c|}{$\begin{array}{c}\text { Yes } \\
\text { Fiscal Rules Binding }\end{array}$}} & & \multirow{3}{*}{ No } & \multirow{2}{*}{\multicolumn{2}{|c|}{$\begin{array}{c}\text { Yes } \\
\text { Fiscal Rules Binding }\end{array}$}} \\
\hline & & & & & & & \\
\hline & & No & Yes & & & No & Yes \\
\hline \multicolumn{4}{|c|}{ Output } & \multicolumn{4}{|c|}{ Primary deficit } \\
\hline Core $(y)$ & -1.1 & -0.6 & -0.4 & Core $(f)$ & 1.7 & 1.4 & 1.1 \\
\hline Periphery $\left(y^{*}\right)$ & -4.6 & -2.2 & -3.1 & Periphery $\left(f^{*}\right)$ & 2.3 & 5.8 & 0.8 \\
\hline Aggregate $(\bar{y})$ & -2.8 & -1.4 & -1.8 & Central $\left(f^{\epsilon}\right)$ & 0.0 & 2.6 & 3.3 \\
\hline \multicolumn{4}{|c|}{ Inflation } & \multicolumn{4}{|c|}{ Debt } \\
\hline Core $(\pi)$ & -0.3 & -0.1 & -0.1 & Core $(b)$ & 2.4 & 2.1 & 1.7 \\
\hline Periphery $\left(\pi^{*}\right)$ & 0.2 & 1.4 & 0.9 & Periphery $\left(b^{*}\right)$ & 8.5 & 8.3 & 4.5 \\
\hline Aggregate $(\bar{\pi})$ & 0.0 & 0.6 & 0.4 & Central $\left(b^{\in}\right)$ & 0.0 & 3.1 & 3.9 \\
\hline \multicolumn{4}{|c|}{ Yields } & \multicolumn{4}{|c|}{ Fiscal stimulus } \\
\hline Core $(r)$ & 0.5 & 3.4 & 2.8 & Core $(g)$ & 1.1 & 1.3 & 1.0 \\
\hline Periphery $\left(r^{*}\right)$ & 2.2 & 5.1 & 3.7 & Periphery $\left(g^{*}\right)$ & 0.0 & 5.3 & 0.0 \\
\hline Eurobond $\left(r^{\epsilon}\right)$ & 0.0 & 2.2 & 1.5 & Central $\left(g^{\in}\right)$ & 0.0 & 2.2 & 2.8 \\
\hline \multicolumn{4}{|c|}{ Bank credit } & \multicolumn{4}{|c|}{ Monetary policy } \\
\hline Core $(l)$ & -1.3 & -7.2 & -5.0 & Policy rate $(i)$ & 0.0 & 1.3 & 0.9 \\
\hline Periphery $\left(l^{*}\right)$ & -21.7 & -19.9 & -18.3 & Assets ( $q)$ & 0.4 & -20.2 & -13.7 \\
\hline
\end{tabular}

Source: Authors' computation

All in all, the combination of adverse supply and bank lending shocks in the periphery may well explain some of the divergences (economic growth, inflation, public debt) between the periphery and the core, and the creation of a Eurobond/fiscal capacity could well help reduce these diver- gences. Obviously, this would not argue against tackling the causes of divergence at source - i.e. the lack of structural reform in the periphery. However, it could help to ease the pain of divergence to muster more political support for reform. 
Table 4. Shock-Responses - Leading Core.

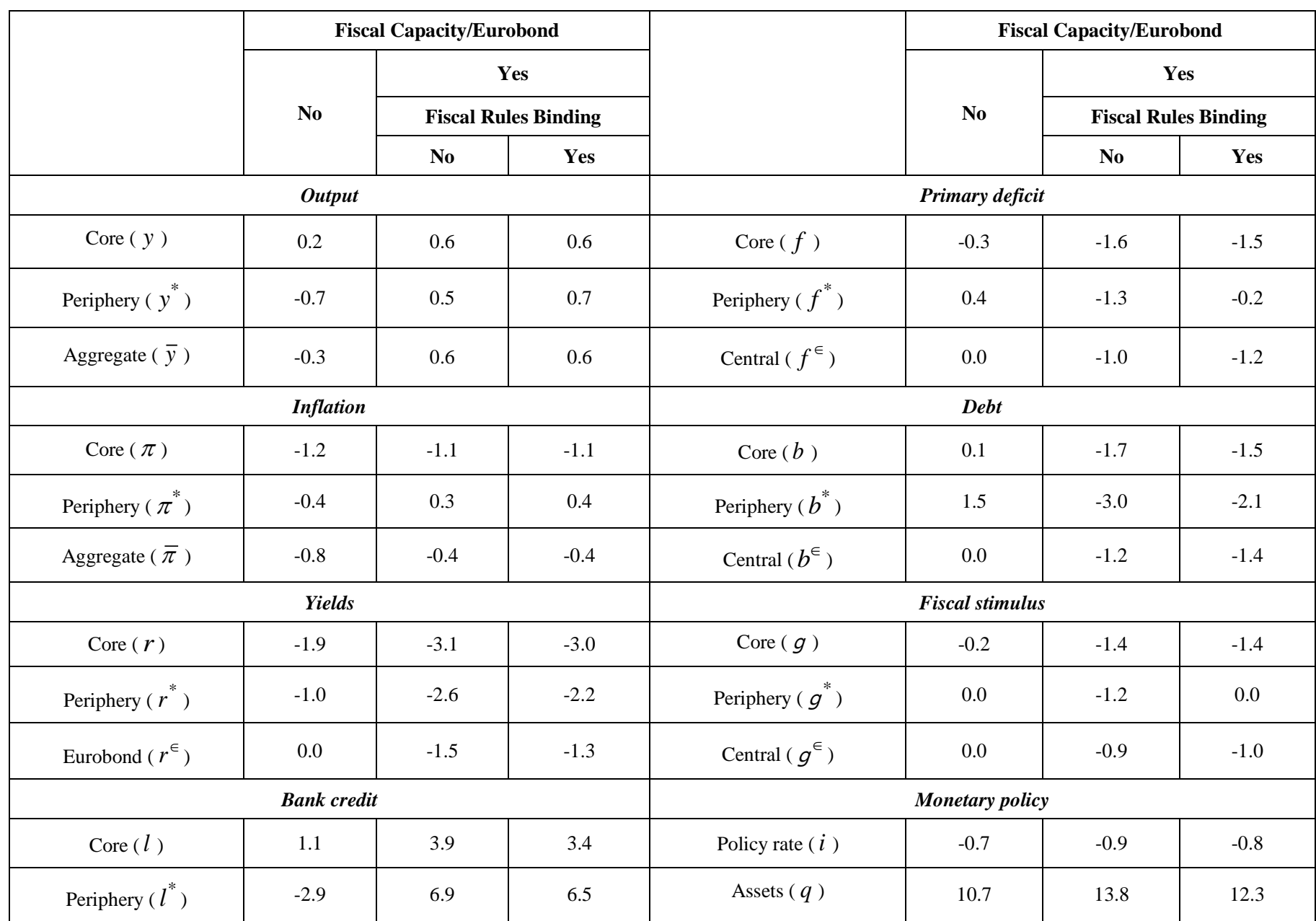

Source: Authors' computations.

\subsection{Leading Core}

As noted, it is a generally accepted view that the core has been more forthcoming than the periphery in terms of structural reform, at least before the crisis, and has also benefited from the safe-haven properties of their sovereign bonds. This is yet another source of divergence, as suggested by the simulation results:

1. In the absence of a Eurobond/fiscal capacity (scenario I in Table 4), output developments in the periphery and core indeed diverge at the detriment of the former, as do yields. Bank lending is comparatively weak in the periphery, actually contracting, due to weak macroeconomic conditions. However, the primary deficit and public debt are falling in the core and increasing in the periphery. Monetary policy is eased, both conventional and nonconventional.

2. With the creation of a Eurobond/fiscal capacity, regardless of whether or not fiscal policy is constrained in the periphery (scenarios IIa and IIb in Table 4), the divergences vanish and output is generally much stronger across the board, supported by very easy monetary policy (conventional and nonconventional) and buoyant bank lending.
To sum up, to the extent core-periphery divergences stem from structural reform efforts in the core, the bulk of this divergence disappears with the creation of a Eurobond/fiscal capacity, mostly because the contraction of bank credit in the periphery would halt.

\subsection{Alternative Assumptions}

In the simulations discussed above some crucial assumptions were made about the responses of bank lending, sovereign bond yields and fiscal policy that may not be satisfied in reality. In this section, we will examine the impact of these assumptions by way of a robustness check.

First, so far, we have assumed that after the creation of the Eurobond supported by a quantitative easing programme to which only the Eurobond is eligible, asset purchases by the ECB will stimulate bank lending via the direct bank lending channel (i.e. the conversion of reserves into bank loans to the private sector). However, the evidence in the empirical literature of this channel being active in jurisdictions where banks have access to a safe asset is somewhat mixed. Hence it would be useful to run the same set of simulations as above, but now assuming that this channel is comparatively weak. Specifically, we set the relevant parameters in the bank lending equations (5) at half their baseline values, i.e. 
$\xi_{2}=0.006$ and $\xi_{2}^{*}=0.125$. This assumption will not change the simulation results for the "current situation" in which the bank lending channel is absent in any case.

The results - reported in Tables A1-A3 in the Annex - show that identical results for the real economy are obtained after the adoption of the Eurobond/fiscal capacity as in the baseline model, but to achieve this in the 'Great Financial Crisis' and 'leading core' scenarios much stronger monetary responses (conventional and non-conventional) are needed to compensate for the weaker bank lending channel. Conversely, in the 'lagging periphery' scenario a comparatively strong quantitative tightening response is required to keep inflation under control - illustrating that monetary policy at large is not well suited to absorb adverse supply shocks. Overall, the new set-up with a Eurobond and fiscal capacity retains its better stabilization properties, notwithstanding the weaker bank lending channel, but this comes with stronger monetary policy support for bank lending.

Second, we have thus far assumed that the yield on the Eurobond reflects monetary policy and expectations thereof, but not fiscal developments at the supranational level. Due to the guarantee that underpins the Eurobond, the latter are, in contrast, reflected in the yields of national sovereigns. This is based on the premise that the guarantee is credible, and hence supranational debt should affect the yields on national sovereign bonds only, not the yield on the Eurobond. However, if the guarantee is not credible - at least not initially until a sufficient track record is established - the Eurobond yield should incorporate a default risk premium reflecting supranational fiscal developments. As well, the default risk premium should be correspondingly smaller on national sovereign debt as this risk is now transferred to the Eurobond market. This means that the spreads of national sovereigns against the Eurobond should narrow relative to the baseline. However, in this situation, Eurobonds on the balance sheet of banks are unlikely to be perceived to be safe in crises, which would adversely affect banks' funding cost. This is why even with Eurobonds in place - a lender of last resort commitment of the ECB (in the form of a mandate for purchases of Eurobonds) remains crucial (see for instance De Grauwe and $\mathrm{Ji}, 2018$ ).

Tables A4-A6 in Annex A report again the same set of simulations as those reported in Tables $\mathbf{2 - 4}$, but now using a different set of yield and bank lending equations to reflect the above considerations. Specifically, the yield equations now read

$$
\begin{aligned}
& r^{*}=s r^{\epsilon}+(1-s)\left(\vartheta_{1} i-\vartheta_{2} q\right)+\vartheta_{3} b+\rho \\
& r^{*}=s r^{\epsilon}+(1-s)\left(\vartheta_{1}^{*} i-\vartheta_{2}^{*} q\right)+\vartheta_{3}^{*} b^{*}+\rho^{*} \\
& r^{\epsilon}=(1-s) \frac{1}{2}\left(r-r^{*}\right)+s\left(\sigma_{1} i-\sigma_{2} q+\sigma_{3} s b^{\epsilon}+\rho^{\epsilon}\right)
\end{aligned}
$$

where we assume that $\sigma_{3}$ equals the average of $\vartheta_{3}$ and $\vartheta_{3}^{*}$, so $\sigma_{3}=0.245$. Hence supranational debt now enters the yield equation for the Eurobond but is eliminated from the national yield equations. This implies that increases in supranational debt affect the national sovereign yields indirectly - via the benchmark Eurobond yield - as opposed to the baseline model in which the periphery is directly exposed to supranational default risk. Moreover, the bank lending equations now read:

$$
\begin{aligned}
& l-(y+\pi)=-\xi_{1} i+s \xi_{2} q-1(1-s) \xi_{3}\left(r-r^{*}\right)-s \xi_{4} r^{\epsilon}+\lambda \\
& l^{*}-\left(y^{*}+\pi^{*}\right)=-\xi_{1}^{*} i+s \xi_{2}^{*} q-1(1-s) \xi_{3}^{*}\left(r^{*}-r\right)-s \xi_{4}^{*} r^{\epsilon}+\lambda^{*}
\end{aligned}
$$

This means that if $s=1$ (Eurobond and fiscal capacity in place), an increase in the yield on Eurobonds would adversely affect the quality of banks' balance sheets and hence their funding cost, which in turn would lead to a contraction of bank credit. This mechanism, moreover, would be effective in both the periphery and the core as banks in both blocks would be exposed to this risk. As to the numerical calibration, we assume that $\xi_{4}^{*}=\xi_{3}^{*}$ and $\xi_{4}^{*}=\xi_{3}^{*} / 2$ to reflect the smaller exposure to sovereign debt in core banks than in periphery banks. The thrust of the simulation results for the "Great Financial Crisis" shock does not change, with the contractionary impact of the shock on output much more muted with a Eurobond/fiscal capacity than without these devices. However, the main difference with the baseline version of the model is that bank lending now contracts even with a Eurobond and fiscal capacity in place due to the exposure to supranational default risk, though not as much as in the "current" situation without these devices. Because the effectiveness of asset purchases by the ECB is stronger in this version of the model than in the baseline version (given that there is an additional channel via the funding cost of banks), less of it is needed. The greater effectiveness of asset purchases also creates room for fiscal stimulus at the center. The other simulations portray a similar bias relative to the baseline, that is a more muted response of bank lending and a stronger reliance on fiscal policy at the center, without however affecting the thrust of the outcomes in terms of macroeconomic stabilisation.

Finally, we have so far assumed that national fiscal policy in the core is unconstrained, but in practice, ideological priors may stop the periphery from conducting an active fiscal stabilization policy in the face of adverse shocks. If so, the impact of the shocks on output will tend to be larger in the periphery, and therefore the responses of monetary policy as well as supranational fiscal policy (once centralised fiscal capacity is created) will be stronger. This is indeed the picture that emerges from the simulations reported in Tables A7-A9, in which it is assumed that always $g=0$. However, aside from the different policy responses, there are no other significant differences relative to the baseline simulations as reported in Tables 2-4.

All in all, these alternative simulations do not change our overall assessment that the creation of Eurobonds and fiscal capacity at the centre, with the ECB acting as a lender of last resort, renders the monetary union considerably more resilient to the sort of shocks it has experienced to date. 


\section{CONCLUSIONS}

This paper extends the analysis developed in Codogno and Van den Noord (2019) by including explicit modelling of bond yields, bank lending and public debt dynamics in a stylised Eurozone formed by a core country and a periphery country. The requirement of reducing moral hazard while introducing a form of risk-sharing is achieved by engineering both fiscal capacity and a Eurobond at the centre that eliminates the 'doom loop' that affected the periphery in the past.

Starting from a baseline version of the model to describe the current situation, we modify it to include (i) a single Eurobond to replace national bonds on banks' and ECB's balance sheets, (ii) a Eurozone fiscal capacity, and (iii) a new quantitative easing scheme that mandates the ECB to adjust its portfolio of Eurobonds as needed in the pursuit of price stability. We resort to the numerical calibration of the parameters in line with Codogno and Van den Noord (2019) and other available literature estimates.

As concerns the financial and government sectors we develop a stylised specification that allows for financial riskpremium shocks in line with the predicament of the so-called 'doom loop' by explicitly modelling bond yields, bank lending and public debt dynamics. Numerical assumptions are again based on mainstream literature.

Once the model is developed, we derive optimal policy rules, including fiscal policy at the centre, by assuming the respective authorities minimise the welfare loss gauged by the square deviation from equilibrium for their respective policy objectives. We derive solutions for the monetary policy instruments (conventional and non-conventional) and the national fiscal policy stances, also considering the case of binding fiscal rules. Finally, we introduce a welfare loss minimisation equation for the supra-national fiscal policy stance and

\section{APPENDIX: ALTERNATIVE SIMULATIONS}

Table A1. Shock-Responses -- the Great Financial Crisis and Aftermath with a Weak Direct Bank Lending Channel.

\begin{tabular}{|c|c|c|c|c|c|c|c|}
\hline & \multicolumn{3}{|c|}{ Fiscal Capacity/Eurobond } & & \multicolumn{3}{|c|}{ Fiscal Capacity/Eurobond } \\
\hline & \multirow{3}{*}{ No } & \multirow{2}{*}{\multicolumn{2}{|c|}{$\begin{array}{c}\text { Yes } \\
\text { Fiscal Rules Binding } \\
\end{array}$}} & & \multirow{3}{*}{ No } & \multirow{2}{*}{\multicolumn{2}{|c|}{$\begin{array}{c}\text { Yes } \\
\text { Fiscal Rules Binding }\end{array}$}} \\
\hline & & & & & & & \\
\hline & & No & Yes & & & No & Yes \\
\hline \multicolumn{4}{|c|}{ Output } & \multicolumn{4}{|c|}{ Primary Deficit } \\
\hline Core $(y)$ & -4.1 & -1.3 & -1.2 & Core $(f)$ & 6.3 & 3.3 & 3.1 \\
\hline Periphery $\left(y^{*}\right)$ & -6.7 & -1.1 & -1.5 & Periphery $\left(f^{*}\right)$ & 3.3 & 2.7 & 0.4 \\
\hline Aggregate $(\bar{y})$ & -5.4 & -1.2 & -1.3 & $\operatorname{Central}\left(\bar{f}^{\in}\right)$ & 0.0 & 2.2 & 2.5 \\
\hline \multicolumn{4}{|c|}{ Inflation } & \multicolumn{4}{|c|}{ Debt } \\
\hline Core $(\pi)$ & -1.0 & -0.3 & -0.3 & Core $(b)$ & 8.8 & 4.0 & 3.7 \\
\hline Periphery $\left(\pi^{*}\right)$ & -3.3 & -0.5 & -0.7 & Periphery $\left(b^{*}\right)$ & 17.0 & 5.2 & 3.3 \\
\hline Aggregate $(\overline{\bar{\pi}})$ & -2.2 & -0.4 & -0.5 & Central $\left(b^{\in}\right)$ & 0.0 & 2.6 & 3.0 \\
\hline \multicolumn{4}{|c|}{ Yields } & \multicolumn{4}{|c|}{ Fiscal Stimulus } \\
\hline
\end{tabular}

numerical weights for the coefficients.The inertia of both monetary and fiscal policy is much larger without a Eurobond/fiscal capacity due to large impact-response multipliers of the 'doom loop'.

Solving the system for all goals and policy instruments and introducing demand, supply, bank lending, and sovereign risk premium shocks, with and without Eurobond/fiscal capacity gives interesting results.

In various scenarios, output is much harder hit in the periphery than in the core, notwithstanding the assumed symmetry of the demand shocks, which not surprising given the 'doom loop'. Despite the working of automatic stabilisers, conventional and non-conventional monetary policy cannot prevent a significant economic slump. Instead, the introduction of Eurobonds/fiscal capacity can provide substantial demand offset, with a much more muted increase in government debt in the periphery and a more modest monetary policy response. This supports the view that the combination of these two instruments can effectively rebalance policies. The picture does not change significantly with the introduction of binding fiscal rules.

To sum up, had fiscal capacity existed at the onset of the crisis, the recession would have been much more muted. More importantly, macroeconomic stabilisation would become much more effective in the future should other shocks hit the Eurozone.

The model is robust to the introduction of alternative assumptions, confirming that the Eurobonds/fiscal capacity make the Eurozone economy much more resilient to macroeconomic shocks.

\section{CONFLICT OF INTEREST STATEMENT}

The authors declare that they have no conflict of interest. 


\begin{tabular}{|c|c|c|c|c|c|c|c|}
\hline Core $(r)$ & -0.4 & -1.0 & -1.6 & Core $(g)$ & 4.2 & 3.0 & 2.8 \\
\hline Periphery $\left(r^{*}\right)$ & 2.5 & 1.5 & 0.5 & Periphery $\left(g^{*}\right)$ & 0.0 & 2.5 & 0.0 \\
\hline \multicolumn{4}{|c|}{ Bank credit } & \multicolumn{4}{|c|}{ Monetary policy } \\
\hline Periphery $\left(l^{*}\right)$ & -17.4 & 4.6 & 5.4 & Assets $(q)$ & 29.5 & 27.8 & 33.9 \\
\hline
\end{tabular}

Source: Authors' computations.

Table A2. Shock-Responses - Lagging Periphery with a Weak Direct Bank Lending Channel.

\begin{tabular}{|c|c|c|c|c|c|c|c|}
\hline & \multicolumn{3}{|c|}{ Fiscal Capacity/Eurobond } & & \multicolumn{3}{|c|}{ Fiscal Capacity/Eurobond } \\
\hline & \multirow{3}{*}{ No } & \multirow{2}{*}{\multicolumn{2}{|c|}{$\begin{array}{c}\text { Yes } \\
\text { Fiscal Rules Binding }\end{array}$}} & & \multirow{3}{*}{ No } & \multirow{2}{*}{\multicolumn{2}{|c|}{$\begin{array}{c}\text { Yes } \\
\text { Fiscal Rules Binding }\end{array}$}} \\
\hline & & & & & & & \\
\hline & & No & Yes & & & No & Yes \\
\hline \multicolumn{4}{|c|}{ Output } & \multicolumn{4}{|c|}{ Primary Deficit } \\
\hline Core $(y)$ & -1.1 & -0.6 & -0.4 & Core $(f)$ & 1.7 & 1.4 & 1.1 \\
\hline Periphery $\left(y^{*}\right)$ & -4.6 & -2.2 & -3.1 & Periphery $\left(f^{*}\right)$ & 2.3 & 5.8 & 0.8 \\
\hline Aggregate $(\bar{y})$ & -2.8 & -1.4 & -1.8 & $\operatorname{Central}\left(\bar{f}^{\epsilon}\right)$ & 0.0 & 2.6 & 3.3 \\
\hline \multicolumn{4}{|c|}{ Inflation } & \multicolumn{4}{|c|}{ Debt } \\
\hline Core $(\pi)$ & -0.3 & -0.1 & -0.1 & Core $(b)$ & 2.4 & 2.3 & 1.8 \\
\hline Periphery $\left(\pi^{*}\right)$ & 0.2 & 1.4 & 0.9 & Periphery $\left(b^{*}\right)$ & 8.5 & 8.7 & 4.8 \\
\hline Aggregate $(\overline{\bar{\pi}})$ & 0.0 & 0.6 & 0.4 & Central $\left(b^{\epsilon}\right)$ & 0.0 & 3.2 & 4.0 \\
\hline \multicolumn{4}{|c|}{ Yields } & \multicolumn{4}{|c|}{ Fiscal Stimulus } \\
\hline Core $(r)$ & 0.5 & 5.0 & 3.8 & $\operatorname{Core}(\vartheta)$ & 1.1 & 1.3 & 1.0 \\
\hline Periphery $\left(r^{*}\right)$ & 2.2 & 6.8 & 4.8 & Periphery $\left(\vartheta^{*}\right)$ & 0.0 & 5.3 & 0.0 \\
\hline Eurobond $\left(r^{\mathrm{E}}\right)$ & 0.0 & 3.7 & 2.5 & Central $\left(\vartheta^{\in}\right)$ & 0.0 & 2.2 & 2.8 \\
\hline \multicolumn{4}{|c|}{ Bank Credit } & \multicolumn{4}{|c|}{ Monetary Policy } \\
\hline Core $(l)$ & -1.3 & -7.2 & -5.0 & Policy rate $(i)$ & 0.0 & 1.3 & 0.9 \\
\hline Periphery $\left(l^{*}\right)$ & -21.7 & -19.9 & -18.3 & Assets ( $q)$ & 0.4 & -40.5 & -27.4 \\
\hline
\end{tabular}

Source: Authors' computations.

Table A3. Shock-Responses - Leading Core with a Weak Direct Bank Lending Channel.

\begin{tabular}{|c|c|c|c|c|c|c|c|}
\hline & \multicolumn{3}{|c|}{ Fiscal Capacity/Eurobond } & & \multicolumn{3}{|c|}{ Fiscal capacity/Eurobond } \\
\hline & \multirow{3}{*}{ No } & & & & \multirow{3}{*}{ No } & \multicolumn{2}{|c|}{ Yes } \\
\hline & & \multicolumn{2}{|c|}{ Fiscal Rules Binding } & & & \multicolumn{2}{|c|}{ Fiscal Rules Binding } \\
\hline & & No & Yes & & & No & Yes \\
\hline \multicolumn{4}{|c|}{ Output } & \multicolumn{4}{|c|}{ Primary Deficit } \\
\hline Core $(y)$ & 0.2 & 0.6 & 0.6 & Core $(f)$ & -0.3 & -1.6 & -1.5 \\
\hline
\end{tabular}




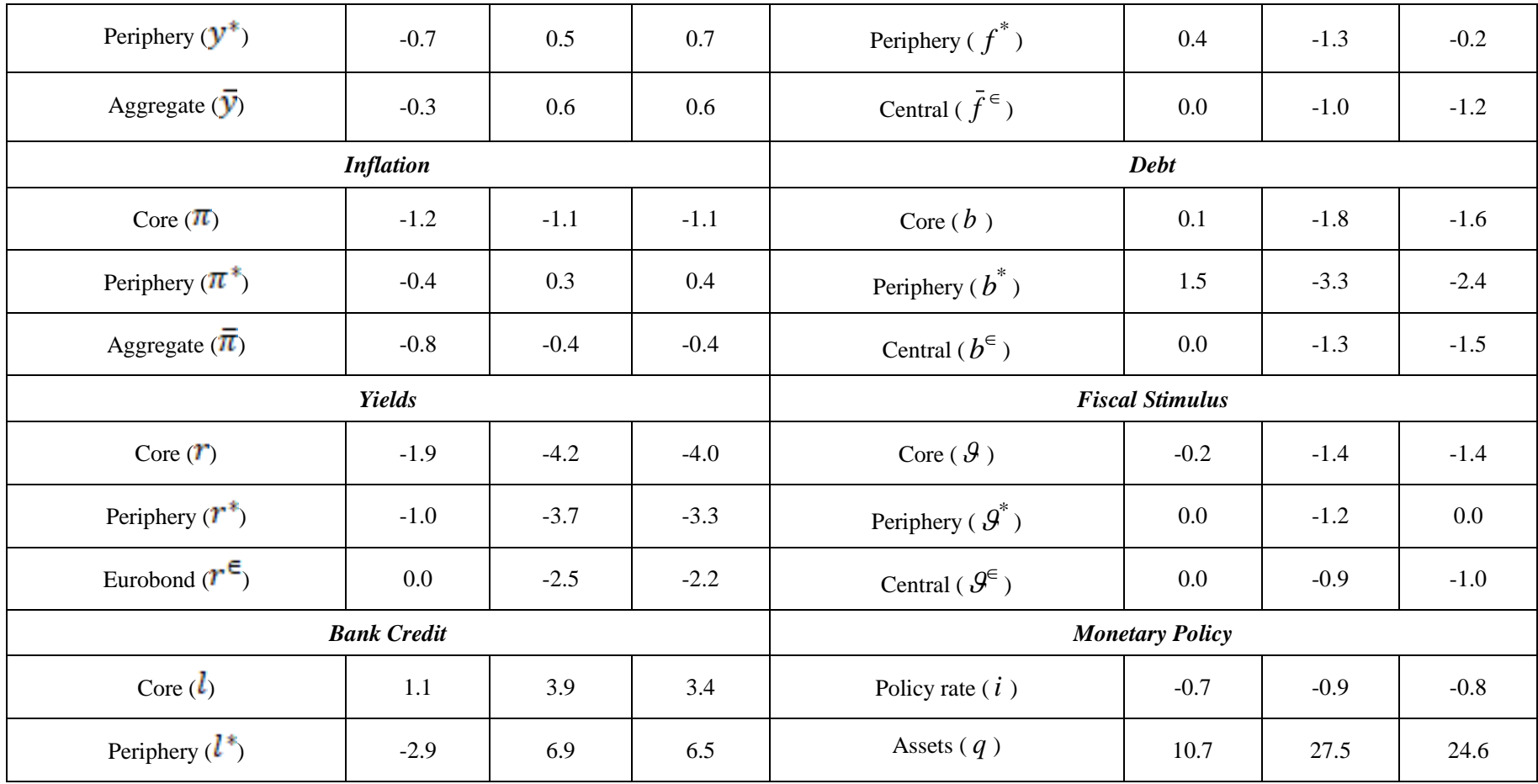

Source: Authors' computations.

Table A4. Shock-Responses -- the Great Financial Crisis and its Aftermath without a Credible Fiscal Guarantee for Eurobonds.

\begin{tabular}{|c|c|c|c|c|c|c|c|}
\hline & \multicolumn{3}{|c|}{ Fiscal Capacity/Eurobond } & & \multicolumn{3}{|c|}{ Fiscal Capacity/Eurobond } \\
\hline & \multirow{3}{*}{ No } & \multirow{2}{*}{\multicolumn{2}{|c|}{$\begin{array}{c}\text { Yes } \\
\text { Fiscal Rules Binding }\end{array}$}} & & \multirow{3}{*}{ No } & \multirow{2}{*}{\multicolumn{2}{|c|}{$\frac{\text { Yes }}{\text { Fiscal Rules Binding }}$}} \\
\hline & & & & & & & \\
\hline & & No & Yes & & & No & Yes \\
\hline \multicolumn{4}{|c|}{ Output } & \multicolumn{4}{|c|}{ Primary Deficit } \\
\hline Core $(y)$ & -4.1 & -1.6 & -1.6 & Core $(f)$ & 6.3 & 3.3 & 3.2 \\
\hline Periphery $\left(y^{*}\right)$ & -6.7 & -1.6 & -2.2 & Periphery $\left(f^{*}\right)$ & 3.3 & 3.2 & 0.5 \\
\hline Aggregate $(\bar{y})$ & -5.4 & -1.6 & -1.9 & Central $\left(f^{\epsilon}\right)$ & 0.0 & 4.6 & 5.4 \\
\hline \multicolumn{4}{|c|}{ Inflation } & \multicolumn{4}{|c|}{ Debt } \\
\hline Core $(\pi)$ & -1.0 & -0.4 & -0.4 & Core $(b)$ & 8.8 & 4.5 & 4.4 \\
\hline Periphery $\left(\pi^{*}\right)$ & -3.3 & -0.8 & -1.1 & Periphery $\left(b^{*}\right)$ & 17.0 & 7.5 & 5.9 \\
\hline Aggregate $(\overline{\bar{\pi}})$ & -2.2 & -0.6 & -0.7 & Central $\left(b^{\epsilon}\right)$ & 0.0 & 5.5 & 6.4 \\
\hline \multicolumn{4}{|c|}{ Yields } & \multicolumn{4}{|c|}{ Fiscal Stimulus } \\
\hline Core $(r)$ & -0.4 & 1.6 & 1.7 & Core $(\vartheta)$ & 4.2 & 2.9 & 2.9 \\
\hline Periphery $\left(r^{*}\right)$ & 2.5 & 4.6 & 4.2 & Periphery ( $\left.\vartheta^{*}\right)$ & 0.0 & 2.8 & 0.0 \\
\hline Eurobond $\left(r^{\mathrm{E}}\right)$ & 0.0 & 0.6 & 0.7 & Central ( $\vartheta^{\in}$ ) & 0.0 & 4.2 & 4.9 \\
\hline \multicolumn{4}{|c|}{ Bank Credit } & \multicolumn{4}{|c|}{ Monetary Policy } \\
\hline Core $(l)$ & 0.7 & -1.0 & -0.5 & Policy rate $(i)$ & -1.9 & -0.6 & -0.7 \\
\hline Periphery $\left(l^{*}\right)$ & -17.4 & -2.0 & -2.4 & Assets $(q)$ & 29.5 & 5.9 & 7.2 \\
\hline
\end{tabular}


Table A5. Shock-Responses - Lagging Periphery without a Credible Fiscal Guarantee for Eurobonds.

\begin{tabular}{|c|c|c|c|c|c|c|c|}
\hline & \multicolumn{3}{|c|}{ Fiscal Capacity/Eurobond } & & \multicolumn{3}{|c|}{ Fiscal capacity/Eurobond } \\
\hline & \multirow{3}{*}{ No } & \multirow{2}{*}{\multicolumn{2}{|c|}{$\frac{\text { Yes }}{\text { Fiscal Rules Binding }}$}} & & \multirow{3}{*}{ No } & \multirow{2}{*}{\multicolumn{2}{|c|}{$\begin{array}{c}\text { Yes } \\
\text { Fiscal Rules Binding }\end{array}$}} \\
\hline & & & & & & & \\
\hline & & No & Yes & & & No & Yes \\
\hline \multicolumn{4}{|c|}{ Output } & \multicolumn{4}{|c|}{ Primary Deficit } \\
\hline Core $(y)$ & -1.1 & -0.4 & -0.3 & Core $(f)$ & 1.7 & 0.8 & 0.7 \\
\hline Periphery $\left(y^{*}\right)$ & -4.6 & -2.5 & -3.4 & Periphery $\left(f^{*}\right)$ & 2.3 & 5.0 & 0.8 \\
\hline Aggregate $(\bar{y})$ & -2.8 & -1.4 & -1.9 & Central $\left(f^{\epsilon}\right)$ & 0.0 & 4.1 & 5.3 \\
\hline \multicolumn{4}{|c|}{ Inflation } & \multicolumn{4}{|c|}{ Debt } \\
\hline Core $(\pi)$ & -0.3 & -0.1 & -0.1 & Core $(b)$ & 2.4 & 1.2 & 1.1 \\
\hline Periphery $\left(\pi^{*}\right)$ & 0.2 & 1.3 & 0.8 & Periphery $\left(b^{*}\right)$ & 8.5 & 7.5 & 5.0 \\
\hline Aggregate $(\bar{\pi})$ & 0.0 & 0.6 & 0.4 & Central $\left(b^{\in}\right)$ & 0.0 & 4.6 & 6.1 \\
\hline \multicolumn{4}{|c|}{ Yields } & \multicolumn{4}{|c|}{ Fiscal Stimulus } \\
\hline Core $(r)$ & 0.5 & 2.1 & 2.2 & $\operatorname{Core}(\vartheta)$ & 1.1 & 0.7 & 0.6 \\
\hline Periphery $\left(r^{*}\right)$ & 2.2 & 3.8 & 3.2 & Periphery $\left(\vartheta^{*}\right)$ & 0.0 & 4.4 & 0.0 \\
\hline Eurobond ( $r^{\epsilon}$ ) & 0.0 & 1.8 & 1.9 & Central ( $\vartheta^{\in}$ ) & 0.0 & 3.7 & 4.9 \\
\hline \multicolumn{4}{|c|}{ Bank Credit } & \multicolumn{4}{|c|}{ Monetary Policy } \\
\hline Core $(l)$ & -1.3 & -7.0 & -6.2 & Policy rate $(i)$ & 0.0 & 0.6 & 0.3 \\
\hline Periphery $\left(l^{*}\right)$ & -21.7 & -22.5 & -23.2 & Assets ( $q$ ) & 0.4 & -5.7 & -3.6 \\
\hline
\end{tabular}

Source: Authors' computations.

Table A6. Shock-Responses - Leading Core without a Credible Fiscal Guarantee for Eurobonds.

\begin{tabular}{|c|c|c|c|c|c|c|c|}
\hline & \multicolumn{3}{|c|}{ Fiscal Capacity/Eurobond } & & \multicolumn{3}{|c|}{ Fiscal capacity/Eurobond } \\
\hline & \multirow[t]{2}{*}{ No } & \multicolumn{2}{|c|}{$\begin{array}{c}\text { Yes } \\
\text { Fiscal Rules Binding }\end{array}$} & & \multirow[t]{2}{*}{ No } & \multicolumn{2}{|c|}{$\begin{array}{c}\text { Yes } \\
\text { Fiscal Rules Binding }\end{array}$} \\
\hline & & No & Yes & & & $N o$ & Yes \\
\hline \multicolumn{4}{|c|}{ Output } & \multicolumn{4}{|c|}{ Primary Deficit } \\
\hline Periphery $\left(y^{*}\right)$ & -0.7 & 0.5 & 0.7 & Periphery $\left(f^{*}\right)$ & 0.4 & -1.0 & -0.2 \\
\hline Aggregate $(\bar{y})$ & -0.3 & 0.5 & 0.6 & Central $\left(f^{\epsilon}\right)$ & 0.0 & -1.4 & -1.7 \\
\hline \multicolumn{4}{|c|}{ Inflation } & \multicolumn{4}{|c|}{ Debt } \\
\hline Aggregate $(\bar{\pi})$ & -0.8 & -0.4 & -0.4 & Central $\left(b^{\in}\right)$ & 0.0 & -1.5 & -1.8 \\
\hline \multicolumn{4}{|c|}{ Yields } & \multicolumn{4}{|c|}{ Fiscal Stimulus } \\
\hline Core $(r)$ & -1.9 & -2.1 & -2.1 & $\operatorname{Core}(\vartheta)$ & -0.2 & -0.9 & -0.9 \\
\hline
\end{tabular}




\begin{tabular}{|c|c|c|c|c|c|c|c|}
\hline Periphery $\left(r^{*}\right)$ & -1.0 & -1.5 & -1.4 & Periphery $\left(\vartheta^{*}\right)$ & 0.0 & -0.9 & 0.0 \\
\hline Eurobond $\left(r^{\epsilon}\right)$ & 0.0 & -0.9 & -0.9 & Central ( $\left.\vartheta^{\in}\right)$ & 0.0 & -1.3 & -1.5 \\
\hline \multicolumn{4}{|c|}{ Bank Credit } & \multicolumn{4}{|c|}{ Monetary Policy } \\
\hline Core $(l)$ & 1.1 & 3.2 & 3.1 & Policy rate $(i)$ & -0.7 & -0.4 & -0.4 \\
\hline Periphery $\left(l^{*}\right)$ & -2.9 & 7.1 & 7.3 & Assets $(q)$ & 10.7 & 4.3 & 3.9 \\
\hline
\end{tabular}

Source: Authors' Computations.

Table A7. Shock-responses -- the Great Financial Crisis and its aftermath with fiscal policy in the core constrained.

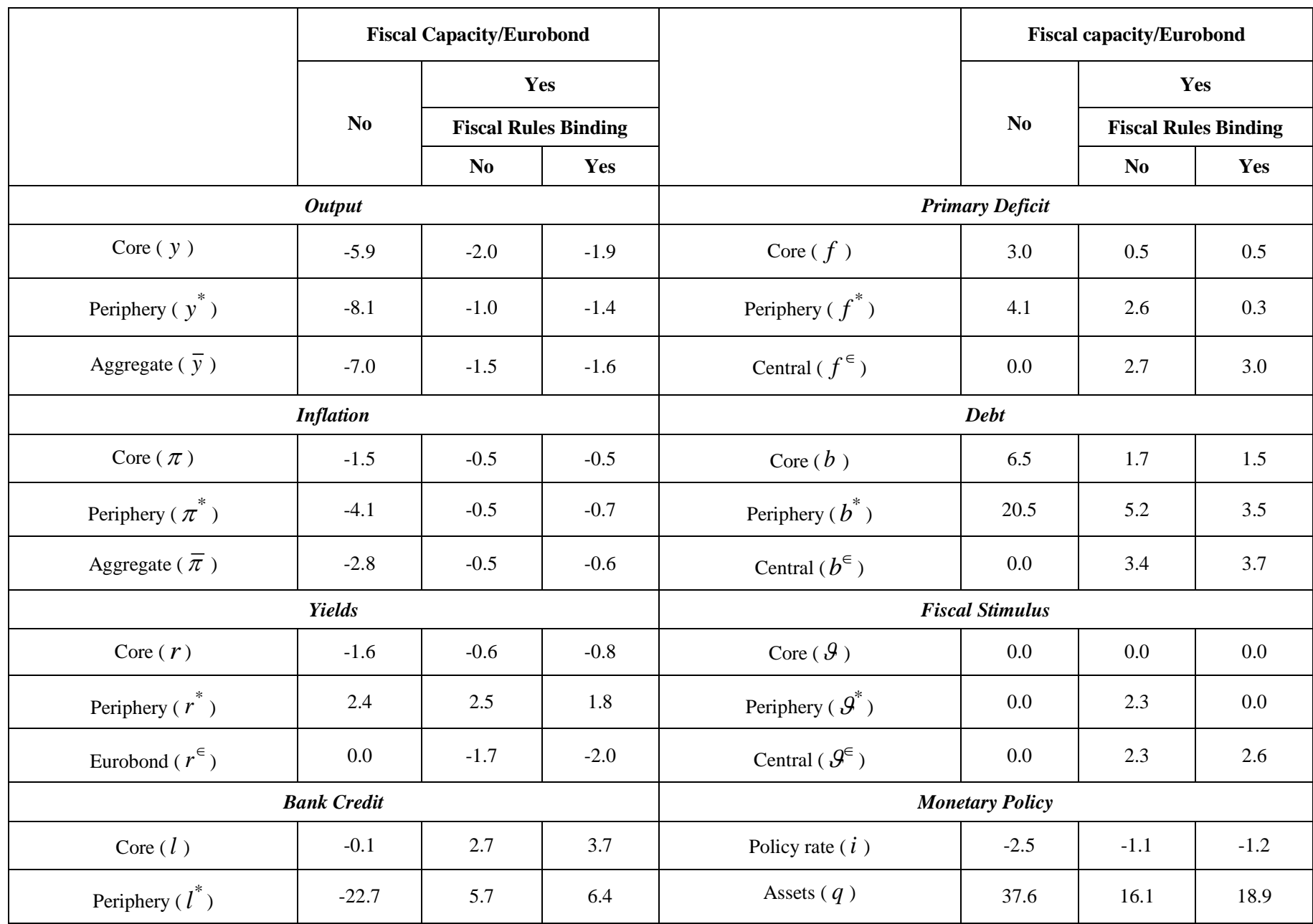

Source: Authors' computations.

Table A8. Shock-Responses - Lagging Periphery with Fiscal Policy in the Core Constrained.

\begin{tabular}{|c|c|c|c|c|c|c|c|}
\hline & \multicolumn{3}{|c|}{ Fiscal capacity/Eurobond } & & \multicolumn{3}{|c|}{ Fiscal capacity/Eurobond } \\
\hline & \multirow{3}{*}{ No } & \multirow{2}{*}{\multicolumn{2}{|c|}{$\begin{array}{c}\text { Yes } \\
\text { Fiscal Rules Binding }\end{array}$}} & & \multirow{3}{*}{ No } & \multicolumn{2}{|c|}{ Yes } \\
\hline & & & & & & \multicolumn{2}{|c|}{ Fiscal Rules Binding } \\
\hline & & No & Yes & & & No & Yes \\
\hline \multicolumn{4}{|c|}{ Output } & \multicolumn{4}{|c|}{ Primary Deficit } \\
\hline Core $(y)$ & -1.6 & -0.9 & -0.7 & Core $(f)$ & 0.8 & 0.2 & 0.2 \\
\hline Periphery $\left(y^{*}\right)$ & -5.0 & -2.2 & -3.1 & Periphery $\left(f^{*}\right)$ & 2.5 & 5.8 & 0.8 \\
\hline
\end{tabular}




\begin{tabular}{|c|c|c|c|c|c|c|c|}
\hline Aggregate $(\bar{y})$ & -3.3 & -1.5 & -1.9 & Central $\left(f^{\epsilon}\right)$ & 0.0 & 2.8 & 3.4 \\
\hline \multicolumn{4}{|c|}{ Inflation } & \multicolumn{4}{|c|}{ Debt } \\
\hline Core $(\pi)$ & -0.4 & -0.2 & -0.2 & Core $(b)$ & 1.8 & 1.1 & 0.8 \\
\hline Periphery $\left(\pi^{*}\right)$ & 0.0 & 1.4 & 1.0 & Periphery $\left(b^{*}\right)$ & 9.5 & 8.2 & 4.5 \\
\hline Aggregate $(\bar{\pi})$ & -0.2 & 0.6 & 0.4 & Central $\left(b^{\in}\right)$ & 0.0 & 3.4 & 4.1 \\
\hline \multicolumn{4}{|c|}{ Yields } & \multicolumn{4}{|c|}{ Fiscal Stimulus } \\
\hline Core $(r)$ & 0.2 & 3.1 & 2.5 & $\operatorname{Core}(\vartheta)$ & 0.0 & 0.0 & 0.0 \\
\hline Periphery $\left(r^{*}\right)$ & 2.1 & 5.1 & 3.6 & Periphery $\left(\vartheta^{*}\right)$ & 0.0 & 5.2 & 0.0 \\
\hline Eurobond ( $r^{\epsilon}$ ) & 0.0 & 2.1 & 1.4 & Central ( $\vartheta^{\in}$ ) & 0.0 & 2.4 & 3.0 \\
\hline \multicolumn{4}{|c|}{ Bank credit } & \multicolumn{4}{|c|}{ Monetary Policy } \\
\hline Core $(l)$ & -1.5 & -7.3 & -5.0 & Policy rate $(i)$ & -0.2 & 1.3 & 0.9 \\
\hline Periphery $\left(l^{*}\right)$ & -23.1 & -19.4 & -17.9 & Assets ( $q$ ) & 2.6 & -19.3 & -13.0 \\
\hline
\end{tabular}

Source: Authors' computations.

Table A9. Shock-Responses - Leading Core with Fiscal Policy in the Core Constrained.

\begin{tabular}{|c|c|c|c|c|c|c|c|}
\hline & \multicolumn{3}{|c|}{ Fiscal Capacity/Eurobond } & & \multicolumn{3}{|c|}{ Fiscal Capacity/Eurobond } \\
\hline & \multirow{3}{*}{ No } & \multirow{2}{*}{\multicolumn{2}{|c|}{$\begin{array}{c}\text { Yes } \\
\text { Fiscal Rules Binding }\end{array}$}} & & \multirow{3}{*}{ No } & \multirow{2}{*}{\multicolumn{2}{|c|}{$\frac{\text { Yes }}{\text { Fiscal Rules Binding }}$}} \\
\hline & & & & & & & \\
\hline & & No & Yes & & & No & Yes \\
\hline \multicolumn{4}{|c|}{ Output } & \multicolumn{4}{|c|}{ Primary deficit } \\
\hline Core $(y)$ & 0.3 & 0.9 & 0.9 & Core $(f)$ & -0.1 & -0.2 & -0.2 \\
\hline Periphery $\left(y^{*}\right)$ & -0.7 & 0.5 & 0.7 & Periphery $\left(f^{*}\right)$ & 0.3 & -1.3 & -0.2 \\
\hline Aggregate $(\bar{y})$ & -0.2 & 0.7 & 0.8 & Central $\left(f^{\in}\right)$ & 0.0 & -1.3 & -1.4 \\
\hline \multicolumn{4}{|c|}{ Inflation } & \multicolumn{4}{|c|}{ Debt } \\
\hline Core $(\pi)$ & -1.2 & -1.0 & -1.0 & Core $(b)$ & 0.2 & -0.5 & -0.4 \\
\hline Periphery $\left(\pi^{*}\right)$ & -0.3 & 0.2 & 0.3 & Periphery $\left(b^{*}\right)$ & 1.4 & -2.8 & -2.0 \\
\hline Aggregate $(\bar{\pi})$ & -0.8 & -0.4 & -0.3 & Central $\left(b^{\epsilon}\right)$ & 0.0 & -1.5 & -1.7 \\
\hline \multicolumn{4}{|c|}{ Yields } & \multicolumn{4}{|c|}{ Fiscal stimulus } \\
\hline Core $(r)$ & -1.8 & -2.8 & -2.7 & Core $(\vartheta)$ & 0.0 & 0.0 & 0.0 \\
\hline Periphery $\left(r^{*}\right)$ & -1.0 & -2.5 & -2.2 & Periphery $\left(\vartheta^{*}\right)$ & 0.0 & -1.1 & 0.0 \\
\hline Eurobond ( $r^{\in}$ ) & 0.0 & -1.4 & -1.2 & Central ( $\vartheta^{\in}$ ) & 0.0 & -1.1 & -1.2 \\
\hline \multicolumn{4}{|c|}{ Bank credit } & \multicolumn{4}{|c|}{ Monetary policy } \\
\hline Core $(l)$ & 1.1 & 4.0 & 3.5 & Policy rate $(i)$ & -0.7 & -0.8 & -0.7 \\
\hline Periphery $\left(l^{*}\right)$ & -2.6 & 6.4 & 6.1 & Assets ( $q$ ) & 10.3 & 12.7 & 11.3 \\
\hline
\end{tabular}




\section{REFERENCES}

Albertazzi, Ugo, Tiziano Ropele, Gabriele Sene and Frederico M. Signoretti.2012. "The Impact of the Sovereign Debt Crisis on the Activity of Italian Banks", Bank of Italy Occasional Papers 133.

Altavilla, Carlo, Marco Pagano, and Saverio Simonelli. 2016. "Bank Exposures and Sovereign Stress Transmission", European Central Bank Working Paper Series1969, October.

Ball, Laurence M., Daniel Leigh and Prakash Loungani. 2013.“Okun's Law: Fit at 50?", IMF Working Paper WP/13/10.

Barrell, Richard, Dawn Holland, and Ian Hurst. 2012. "Fiscal Multipliers and Prospects for Consolidation", OECD Journal: Economic Studies, 2012(1): 71-102.

Baum, Anja, Marcos Poplawski-Ribeiro, and Anke Weber. 2012."Fiscal Multipliers and the State of the Economy", IMF Working Paper $\mathrm{WP} / 12 / 286$.

Bayoumi, Tamim, Richard B. Harmsen and Jarkko Turunen. 2011."Euro Area Export Performance and Competitiveness", IMF Working Paper WP/11/140.

Beetsma, Roel and Massimo Giuliodori. 2010. "The Macroeconomic Costs and Benefits of the EMU and Other Monetary Unions: an Overview of Recent Research", Journal of Economic Literature 48: 603641.

Buti, Marco and Nicolas Carnot. 2018."The Case for a Central Fiscal Capacity in EMU", VOX CEPR Policy Portal: 7 December.

Buttz, Nick, Rohan Churmz, Michael McMahon, Arpad Morotzz and Jochen Schanz. 2015. "QE and the Bank Lending Channel in the United Kingdom", Warwick Economics Research Paper Series1073: October.

Codogno, Lorenzo, Carlo Favero, and Alessandro Missale. 2003. "Yield Spreads on EMU Government Bonds", Economic Policy37: 505532.

Codogno, Lorenzo and Giordi Galli. 2017. "Can Fiscal Consolidation Be Counterproductive?", Economia Italiana2017/1-2-3: 9-44.

Codogno, Lorenzo and Paul van den Noord. 2019."The Rationale for a Safe Asset and Fiscal Capacity for the Eurozone", pp. 175-204 in The Economics of Monetary Unions: Past Experiences and the Eurozone, edited by Juan E. Castañeda, Alessandro Roselli, and Geoffrey E. Wood, Routledge Studies in the European Economy.

De Grauwe, Paul and Yuemei Ji. 2012."Mispricing of Sovereign Risk and Multiple Equilibria in the Eurozone", CEPS Working Document361, January.

De Grauwe, Paul andYuemeiJi. 2018."Financial Engineering Will Not Stabilise an Unstable Euro Area", VOX CEPR Policy Portal: 19 March.
De Santis, Roberto A. 2016. "Impact of the Asset Purchase Programme on Euro Area Government Bond Yields Using Market News”, ECB Working Paper Series1939: July.

European Central Bank. 2013."Intra-Euro Area Trade Linkages and External Adjustment”, ECB Monthly Bulletin: January.

Fatouh, Mahmoud, Sheri Markose and Simone Giansate. 2019. "The Impact of Quantitative Easing on UK Bank Lending: Why Banks Do Not Lend to Businesses?", Journal of Economic Behavior and Organization March: pp 3-10.

Girouard, Nathalie and Christoph André. 2005."Measuring Cyclicallyadjusted Budget Balances for OECD Countries", OECD Economics Department Working Papers 434.

Joyce, Michael A.S, and Marco Spaltro. 2014. "Quantitative Easing and Bank Lending: a Panel Data Approach", Bank of England Working Paper 504

Kandrac, Jhn and Bernd Schlusche. 2017. "Quantitative Easing and Bank Risk Taking: Evidence from Lending", Finance and Economics Discussion Series 2017-125, Board of Governors of the Federal Reserve System (U.S.).

Llaudes, Ricardo. 2005."The Phillips Curve and Long-Term Unemployment", ECB Working Paper Series441: February.

Paludkiewicz, Karol. 2018. "Unconventional Monetary Policy, Bank Lending, and Security Holdings: the Yield-Induced Portfolio Rebalancing Channel", Deutsche Bundesbank Discussion Paper 22/2018.

Rodnyansky, Alexander and Olivier M. Darmouni. 2017. "The Effects of Quantitative Easing on Bank Lending Behavior, The Review of Financial Studies 30(11): 3858-3887.

Ryan, Ellen, and Karl Whelan. 2019. "Quantitative Easing and the Hot Potato Effect: Evidence from Euro Area Banks", CEPR Discussion Paper 13499.

Schuknecht, Ludger, Jürgenvon Hagen andGuido Wolswijk. 2009. "Government Risk Premiums in the Bond Market: EMU and Canada", European Journal of Political Economy 25: 371-384.

Van den Noord, Paul. 2000. "The Size and Role of Automatic Fiscal Stabilisers in the 1990s and Beyond", OECD Economics Department Working Papers 230, OECD Publishing, Paris.

Van den Noord, Paul. 2019."Are the Current "Automatic Stabilisers" in the Euro Area Member States Sufficient to Smooth Economic Cycles?", European Parliament: May.

Van den Noord, Paul. 2020. "Mimicking a Buffer Fund for the Eurozone", World Economics Journal 21(2): 249-283 